\title{
A SZLOVÁKIAI REGIONÁLIS FEJLESZTÉS- POLITIKA S ANNAK KÖZÉPTÁVÚ DÉL-SZLOVÁKIAI HATÁR MENTI VETÜLETE AZ UNIÓS TÁMOGATÁSPOLITIKA TÜKRÉBEN
}

\author{
(Regional Development Policy in Slovakia and Its Medium \\ Term Appearance in Southern Slovakia's Border Regions \\ Regarding the Development Assistance Policy \\ of the European Union)
}

\section{LELKES GÁBOR}

Kulcsszavak:

regionális politika intézményrendszer Dél-Szlovákia

A tanulmámy a regionális fejlesztéspolitika szlovákiai feltételrendszerét vizsgálja, kiemelve a magyar kisebbség által lakott dél-szlovákiai határ menti sajátosságokat, mely régiót a többségi nemzet fejlesztéspolitikai döntéshozói sokszor hátrányosan diszkriminálnak, elsősorban a többségében szlovák nemzetiségü lakosság által lakott régiók fejlesztését kezelik prioritásként. Az elemzés az uniós csatlakozást megelözö és az azt követő 4 év idösikjáhan mozogva áttekintést ad a politikai körmyezettỏl a regionális intézményrendszeren át a térségfejlesztési stratégiákig, kiemelve a szlovák-magyar határ stratégiai megjelenését az érintett határ menti önkormányzati kerületek gazdasági és szociális fejlesztési programjaiban. A tamulmány továbbá felvázolja az uniós támogatáspolitika szlovákiai megjelenését, számba veszi az elözö, valamint a jelenlegi programozási idöszak alapfeltételrendszerét.

\section{A területfejlesztés politikai keretei}

A regionális politika cél-, eszköz- és intézményrendszerének EU-kompatibilis kiépitése az 1998-ban hivatalba lépett Dzurinda-kormány egyik legnagyobb érdemének tekinthetö. Az 1998-ban felállt kormányzat úgy döntött, hogy a komplex regionális politika müködési, pénzügyi és egyéb feltételeinek a kialakítását prioritásnak tekinti, kormányprogramjában elsődleges célként fogalmazta meg az uniós normáknak megfelelö területfejlesztési törvény kidolgozását, a decentralizáció intézményesítését, a regionális önkormányzatok megszervezését és a regionális finanszírozás reformját. Az 1998-ban megalakult új kormányon belül kormány-alelnöki funkció alakult a régiófejlesztés területének az irányítására, majd 1999-ben létrejött az Épitésügyi és Regionális Fejlesztési Minisztérium, mely az állami közigazgatásban a központi szerv lett a regionális politikát, az építéspolitikát, a lakáspolitikát és a terïletfejlesztést illetően. Az Építésügyi és Regionális Fejlesztési Minisztérium a területi politika szervező intézménye, amely kidolgozza az általános szervezeti és intézményi kereteket, biztosítja a területi fejlesztéshez a programokat és a forrásokat. 
Lelkes Gábor: A szlovákiai regionális fejlesztéspolitika s annak középtávú dél-szlovákiai határ menti vetülete az uniós támogatáspolitika tükrében. - Tér és Társadalom 22. évf. 2008/3. 151-184. p.

Továbbá 1999-ben létrejött még a Szlovák Köztársaság Kormányának a Regionális Politikáért Felelös Tanácsa (mely monitoring, tanácsadói és kezdeményezöi szereppel rendelkezik a kormány regionális fejlesztéspolitikájával kapcsolatosan), valamint az Építésügyi és Regionális Fejlesztési Minisztérium mellett megalakult a Régiófejlesztési Végrehajtó Ügynökség és a Nemzeti Monitoring Bizottság (az uniós források monitoringja és a megfelelỏ regionális politika kialakítása végett).

1999-2001 között a Dzurinda-kormány számos, a régiófejlesztés szempontjából alapvető jelentőségủ dokumentumot és törvénytervezetet fogadott el, ill. készített elö, amelyeknek köszönhetően a regionális politika vagy területfejlesztés erős hatású közpolitikává vált (Hardi-Mezei 2003), közelebb hozva az 1998 előtt elérhetetlennek tủnő EU-tagságot:

- 1999-ben a parlament elfogadta a Szlovák Köztársaság Regionális Fejlesztésének Integrált Tervét, mely a középtávú regionális fejlesztési célkitüzéseket foglalta össze, és meghatározta azokat a régiókat, amelyek elsőbbséget élveznek az elöcsatlakozási támogatások tekintetében ;

- 2000. szeptember 13-án a kormány a 725/2000 számú határozatában elfogadta a Szlovák Köztársaság Regionális Politikájának Alapelvei c. stratégiai dokumentumot, mely a regionális politika típusát, céljait, eszközeit, a területi egységeket és az intézményi keretet határozta meg kapcsolódva a közigazgatás tervezett reformjához;

- 2001 márciusában a 240 sz. határozatában a kormány elfogadta a Nemzeti Regionális Fejlesztés Tervet, mely stratégiai dokumentum átfogó képet nyújt Szlovákia és azon belül az egyes régiók jelenlegi gazdasági és szociális helyzetéről, a további fejlesztési lehetőségek gátjairól, valamint terveket tartalmaz az akadályok leküzdésére a fejlesztési prioritások és stratégiák meghatározásán keresztül;

- a regionális politika alakításával kapcsolatosan mérföldkönek számít a 193/2001 T.t. számú törvény, amelyben törvényi keretek közé lettek foglalva az ipari parkok alapításánál nyújtható állami támogatások;

- a 302/2001 T.t. számú törvény alapján 2002. január 1-jétől a kerületek új jogállást kaptak, az európai szokásoknak megfelelően a középszint is önkormányzati rendszerủvé vált;

- az uniós fejlesztéspolitikai gyakorlat átvételével kapcsolatban lényeges mérföldkőnek számít a 416/2001 T.t. számú törvény, amely jelentős jogkörök átvitelét tette lehetővé az államigazgatási szervektöl (föleg a járási és kerületi hivataloktól) a települési és a kerületi önkormányzatokhoz;

- a regionális politika alapelveinek, valamint az Európai Unió strukturális és kohéziós politikájának szlovákiai érvényesítését az 503/2001 T.t. számú, a Regionális Fejlesztések Támogatásáról szóló alapvető fontosságú törvény tette lehetővé (a nevezett törvény a közigazgatási reformról és a kerületi önkormányzatok, valamint a községek régiófejlesztési kompetenciáiról szóló törvényekhez kapcsolódott, melyekkel egyetemben lehetővé tette az áttekinthetö 
Lelkes Gábor: A szlovákiai regionális fejlesztéspolitika s annak középtávú dél-szlovákiai határ menti vetülete az uniós támogatáspolitika tükrében. - Tér és Társadalom 22. évf. 2008/3. 151-184. p.

TÉT XXII. évf. 2008 — 3 A szlovákiai regionális fejlesztéspolitika... 153

régiófejlesztési támogatási rendszer kialakítását; továbbá kimondta a Regionális Fejlesztést Támogató Ügynökség létrehozását, mint az uniós források irányításáért felelős intézményt);

- az országban tapasztalható nagymértékủ gazdasági és szociális területi egyenlőtlenségek kezelése szempontjából továbbá nagy jelentőséggel bírt az 565/2001 T.t. számú törvény, mely a magas munkanélküliséggel sújtott régiókba történő beruházások állami ösztönzésének a feltételrendszerét fogalmazta meg.

Az EU-val folytatott előcsatlakozási tárgyalások keretében Szlovákia 2001. március 30-án nyitotta meg a regionális politikáról és a strukturális eszközök koordinálásáról szóló fejezetet. A több mint egy évig tartó tárgyalások során elfogadásra kerültek mindazon dokumentumok és törvények, amelyek nélkül az ország nem juthatott volna hozzá az uniós forrásokhoz (a Szlovák Köztársaság Vidékfejlesztési Terve, a Nemzeti Környezetvédelmi Akcióterv stb.). A regionális politikáról és a strukturális eszközök koordinálásáról szóló fejezetet Szlovákia és az EU 2002. július 29-én zárták le.

2003-ban a kormány elfogadta az ország elsỏ Nemzeti Fejlesztési Tervét a 20042006 uniós programozási időszakra vonatkozólag. A dokumentum megfogalmazza az ország kőzéptávú stratégiai fejlesztési prioritásait és az azok eléréséhez vezető utat, meghatározza a 2004-2006 időszak operatív programjait és azok pénzügyi kereteit.

2005 októberében a kormány jóváhagyta a Szlovák Köztársaság Pénzügyminisztériuma által kidolgozott feltétel- és szabályrendszert, melynek alapján individuális állami támogatás nyújtható a munkahelyteremtő beruházóknak.

A kormány számára a 2005 év az EU 2007-2013 programozási időszakára történő stratégiai tervezés időszakát is jelentette, ami végett fokozott ütemben folytatta az ország új, középtávú stratégiai fejlesztési tervének, a Szlovák Köztársaság Nemzeti Stratégiai Referencia Kerete 2007-2013 dokumentumnak a kidolgozását, melynek az első változatát 2005 októberében fogadta el a kormány. A dokumentum elfogadását követően számos hazai és uniós észrevétel született a tervdokumentummal kapcsolatosan, amelyek bedolgozását követően 2006 tavaszán a kormány a 457/2006 sz. kormányrendeletben ismételten elfogadta az ország 2007-2013 programozási időszakra vonatkozó új, középtávú stratégiai fejlesztési tervét. A stratégiai tervdokumentum tartalmazza az ország gazdasági és társadalmi felemelkedése végett prioritásként kezelendő területeket és aktivitásokat 2007-2013 közt (melyek számára a forrásokat a Strukturális Alapok és a Kohéziós Alap biztosítják majd).

A 2006 nyarán bekövetkezett kormányváltás után a hatalmat megszerzö Ficokormány ezen stratégiai tervdokumentumot átdolgozta, majd a kormány által 2006 telén elfogadott dokumentum került Brüsszelbe, s szolgált kiindulási pontként az Európa Bizottsággal való tárgyalásokon a 2007-2013 programozási idószak támogatási céljainak és feltételeinek véglegesítésére.

A szlovákiai régiók fejlődése szempontjából a Szlovák Köztársaság Nemzeti Stratégiai Referencia Kerete 2007-2013 stratégiai dokumentum mellett a második legmeghatározóbb stratégiai dokumentumnak a Szlovák Köztársaság Nemzeti Stratégiai 
Lelkes Gábor: A szlovákiai regionális fejlesztéspolitika s annak középtávú dél-szlovákiai határ menti vetülete az uniós támogatáspolitika tükrében. - Tér és Társadalom 22. évf. 2008/3. 151-184. p.

Vidékfejlesztési Terve 2007-2013 számít, mely a vidéki térségek társadalmi és gazdasági felemelkedését hivatott koordinálni a 2007-2013 uniós programozási időszakban.

\section{A terïletfejlesztés regionális intézményrendszere}

Bár a területfejlesztés regionális intézményrendszere sokszereplös, a legmeghatározóbb regionális szereplöknek a regionális és a helyi önkormányzatok számítanak. Mindkét önkormányzati szinten az elmúlt fél évtizedben kiépült az EU-konform intézményrendszer, megalakultak az önkormányzati képviselőtestületek területfejlesztési bizottságai, valamint az önkormányzati hivatalok területfejlesztési szakosztályai. Az 503/2001 Tt. törvény értelmében mind a 8 regionális önkormányzat rendelkezik az önkormányzati képviselötestület által jóváhagyott területfejlesztési stratégiával, amely kötelező érvényủ az adott regionális önkormányzat számára (1. ábra). A helyi önkormányzatok többsége szintén rendelkezik a törvény által elöirt stratégiai fejlesztési tervekkel (a stratégiai tervek hiánya leginkább az aprófalvakban fordul elö, ahol a szűkös pénzforrások nem teszik lehetövé ezen dokumentumok kidolgozását).

A fentiekben említett két szereplö - a regionális és a helyi önkormányzatok - mellett a régiók felemelkedésében fontos szerepet játszanak még a különféle tanácsadó és közvetítő szervezetek és intézmények, amelyek információátadással jelentősen növelhetik a régió lakosságának, vállalkozásainak és intézményeinek versenyképességét, elősegíthetik egy-egy régión belül az életszínvonal minőségbeli növekedését. Szlovákiában számos köz- és magánintézmény igyekszik ezen említett szolgáltatásokat nyújtani a régiók irányába, melyek közül a területfejlesztést leglényegesebben elösegítő intézményeknek a Regionális Fejlesztési Ügynökségek Integrált Hálózata és a Szlovák Nemzeti Kis-és Középvállalkozás-fejlesztési Ügynökség számítanak.

\section{1. ÁBRA}

Az önkormányzatok területfejlesztési intézményrendszere (Regional Development Institutional System of Self-governments)

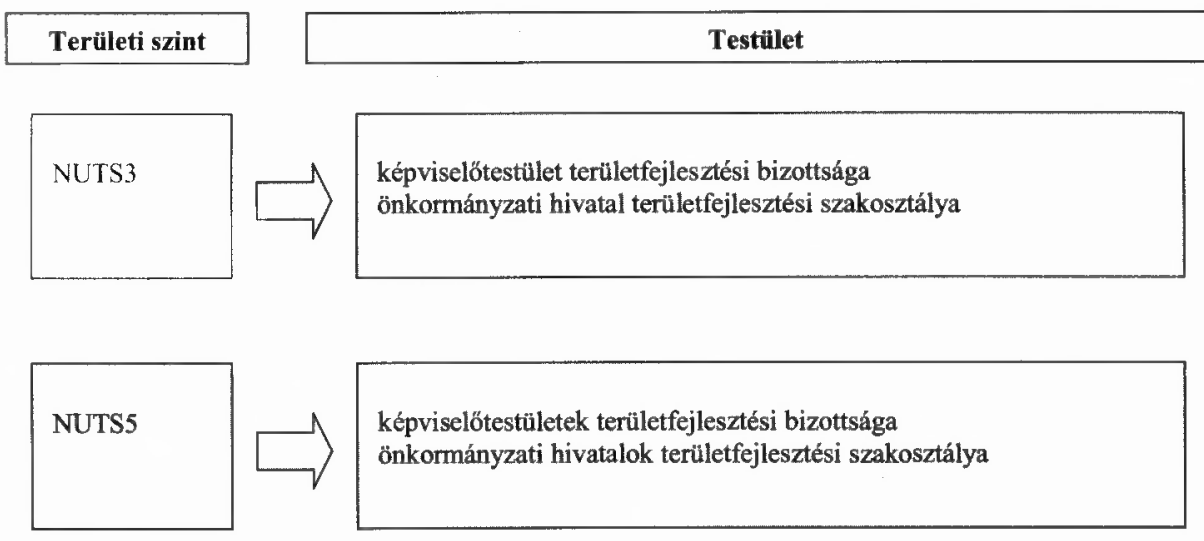

Forrás: Saját szerkesztés. 
Lelkes Gábor: A szlovákiai regionális fejlesztéspolitika s annak középtávú dél-szlovákiai határ menti vetülete az uniós támogatáspolitika tükrében. - Tér és Társadalom 22. évf. 2008/3. 151-184. p.

A szlovákiai regionális fejlesztéspolitika...155

A szlovákiai régiók fejlesztésében a legjelentősebb intézményi háttérrendszerrel az Szlovák Köztársaság Építésügyi és Regionális Fejlesztési Minisztériuma által támogatott Regionális Fejlesztési Ügynökségek Integrált Hálózata rendelkezik. A hálózat kiépítése 2000 szeptemberében kezdỏdött el (a 738/2000 számú kormányhatározat alapján), melyet 2007 júniusában az ország 34 városában 34 iroda képviselt, ebből 13 a magyarlakta dél-szlovákiai régió városaiban volt (2. ábra). A hálózatba tartozó regionális fejlesztési ügynökségek (RFÜ) jogi személyek társulásaként jöttek létre, s nonprofit szervezetként müködnek. Az RFÜ-k rendkivül fontos szerepet töltenek be az ügynökségekhez tartozó térség gazdasági fejlödésében, a helyi és regionális partnerségek kialakításában, a fejlesztési programok megtervezésében, koordinálásában.

\section{2. ÁBRA}

A Regionális Fejlesztési Ügynökségek Integrált Hálózatába tartozó dél-szlovákiai regionális fejlesztési ügynökségek terïleti fekvése a számottevö magyar kisebbséggel rendelkezö 16 dél-szlovákiai járásban

(Location of Regional Development Agencies - Belonging to the Integrated Network of Regional Development Agencies in Slovkia - in Southern Slovakian Districts Inhabitated with Large Number of Hungarian Minority)

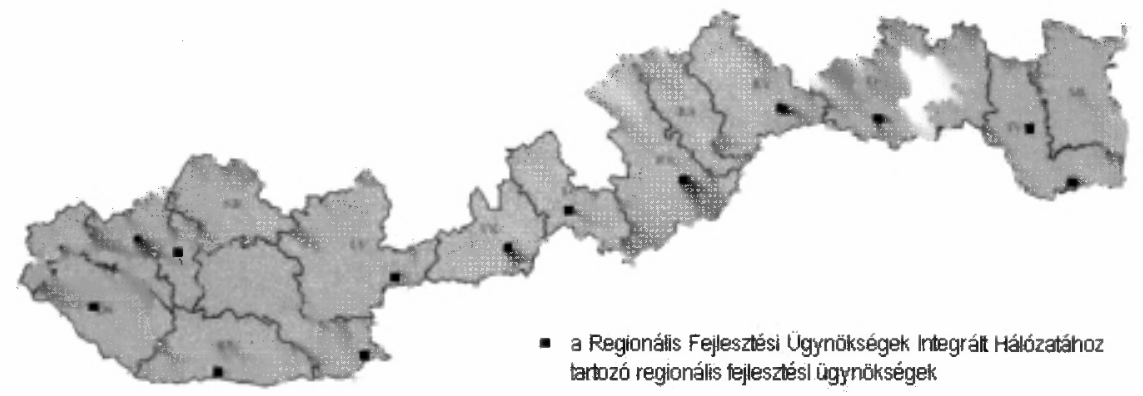

Megjegyzés: A 16 dél-szlovákiai járás: Szenc (SC), Galánta (GA), Dunaszerdahely (DS), Vágsellye (SA), Nyitra (NR), Érsekújvár (NZ), Komárom (KN), Léva (LV), Nagykürtös (VK), Losonc (LC), Rimaszombat (RS), Nagyróce (RA), Rozsnyó (RV), Kassa kömyék (KO), Tóketerebes (TV), Nagymihály (MI)

Forrás: Saját szerkesztés.

Fő tevékenységüket tekintve az RFÜ-k információs pontokat jelentenek az uniós forrásokkal kapcsolatosan, valamint szerepet vállalnak:

- a regionális fejlesztési stratégiák és koncepciók kialakításában;

- nem beruházási (pl. helyi és térségi fejlesztési tervek, területrendezési tervek, vállalkozói tervek elkészítése stb.) és beruházási (pl. vállalkozói házak építése, idegenforgalmi infrastruktúra rekonstrukciója stb.) programok, projektumok és tevékenységek megtervezésében és megvalósításában;

- workshopok és konferenciák rendezésében;

- információs és tanácsadói szolgáltatásokban nonprofit szervezetek, vállalkozók, községek és városok számára uniós és egyéb pályázatokkal és programokkal kapcsolatban;

- vállalkozói tervek elkészítésében. 
Lelkes Gábor: A szlovákiai regionális fejlesztéspolitika s annak középtávú dél-szlovákiai határ menti vetülete az uniós támogatáspolitika tükrében. - Tér és Társadalom 22. évf. 2008/3. 151-184. p.

A Szlovák Köztársaság Építésügyi és Regionális Fejlesztési Minisztériuma által támogatott Regionális Fejlesztési Ügynökségek Integrált Hálózata mellett az elmúlt fél évtizedben az önkormányzati kerületek is elkezdték kiépiteni a maguk saját regionális fejlesztési ügynökségi hálózatát, amely intézmények a minisztériumi regionális fejlesztési ügynökségekhez hasonlóan jogi személyek társulásaként vannak létrehozva (az alapítók kőzt ott szerepel az adott kerületi önkormányzat), s nonprofit szervezetként múködnek.

A Szlovák Nemzeti Kis- és Középvállalkozás-fejlesztési Ügynökség a mai formában 1997-ben alakult három intézményi alapitóval: a Szlovák Köztársaság Gazdasági Minisztériuma, a Szlovákia Vállalkozóinak Szövetsége és a Szlovák Vállalkozók Uniója hozta létre a vállalkozás- és innováció-ösztönzési tevékenységet kifejtó szervezetet. A Szlovák Nemzeti Kis- és Középvállalkozás-fejlesztési Ügynökség 2007 júniusában a dél-szlovákiai tér 6 városában múködtetett tanácsadói központot, mely intézményeknek fö küldetése a kis- és középvállalkozások támogatása komplex információs és tanácsadó szolgáltatásokon, valamint oktatási programokon keresztül (3. ábra).

\section{3. ÁBRA}

A Szlovák Nemzeti Kis- és Középvállalkozás-fejlesztési Ügynökség által létrehozott dél-szlovákiai tanácsadói központok a kis- és középvállalkozások müködésének elösegitése érdekében (Location of Regional Advisory and Information Centres - Established by National Agency for Development of Small and Medium Enterprises -in Southern Slovakia to

Support Small and Medium Enterprises)

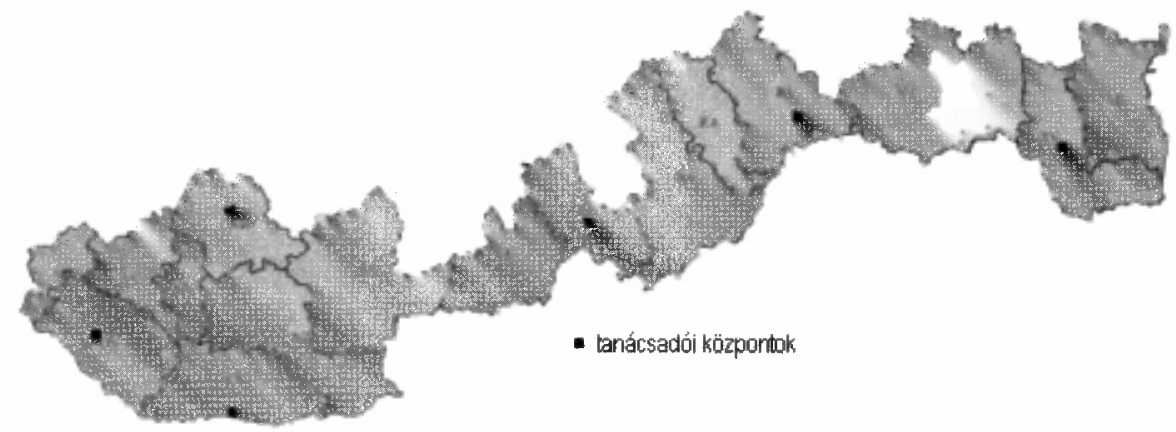

Megjegyzés: A 16 dél-szlovákiai járás: Szenc (SC), Galánta (GA), Dunaszerdahely (DS), Vágsellye (SA), Nyitra (NR), Érsekújvár (NZ), Komárom (KN), Léva (LV), Nagykürtös (VK), Losonc (LC), Rimaszombat (RS), Nagyröce (RA), Rozsnyó (RV), Kassa kömyék (KO), Tỏketerebes (TV), Nagymihály (MI)

Forrás: Saját szerkesztés.

\section{Eurorégiók - fokozatosan erösödö intézményi szereplök}

A határon átnyúló fejlesztési tevékenységet ösztönző euroregionális együttmüködési intézmények a határ menti régiók megújítási képességét elősegitő regionális intézményi infrastruktúra meghatározó elemeinek számítanak, meghatározó szerep- 
Lelkes Gábor: A szlovákiai regionális fejlesztéspolitika s annak középtávú dél-szlovákiai határ menti vetülete az uniós támogatáspolitika tükrében. - Tér és Társadalom 22. évf. 2008/3. 151-184. p. A szlovákiai regionális fejlesztéspolitika...157

pel bírnak a határ menti régiók gazdasági és szociális fejlödésében az államhatárokat átlépő gazdasági és szociális kapcsolatok építésével. Ezen együttműködési formák Szlovákiában csak az 1998-ban bekövetkezett kormányváltás után indultak virágzásnak - 1998 elött a Szlovákiában uralkodó politikai feszültségek miatt nem léteztek tényleges euroregionális együttmüködések (Mezei 2006).

2007. július 1-jéig - a regionális fejlesztési minisztérium nyilvántartása alapján 12 eurorégió müködött az országban², amelyek közül 8 érintette a szlovák-magyar határt, s amelyek egy kivételtöl eltekintve ${ }^{3}$ kétoldalú (szlovák-magyar) együttmüködési formai kerettel rendelkeztek. A szlovák-magyar határ hosszának csaknem 95\%-a le van fedve eurorégiókkal (némely határszakasz többszörösen), kivételt csupán a főváros környéke képez, míg a legintenzívebb határon átnyúló együttmüködések a Párkány-Kassa tengelyt jellemzik. A Párkány-Kassa határszakaszon található euroregionális együttmúködésekre jellemzö átlagon felüli aktivitás az érintett régió gazdasági elmaradottságának és a nagy természeti korlátok hiányának a következménye (a Párkány-Pozsony határszakaszon a Duna folyó elválasztó szerepe jelentős, melyet fokoz a határátkelési lehetőségek - hidak - hiánya).

\section{Civil szféra - a „Nagy Bumm”}

A civil szféra a területfejlesztés regionális intézményrendszerének fontos szereplője. A célok sokaságának érdekében tömegesen jöttek létre nonprofit szervezetek az elmúlt tíz évben. (A civil szféra robbanásszerü fejlödése a Dzurinda-kormány megalakulását követően indult el 1998-ban.)

A civil társadalom részvétele a községek/városok/régiók fejlesztésében ${ }^{4}$ és irányitásában egészen napjainkig eröteljes növekedést mutat, sőt a közeljövőben a regionális politikában a civil szervezödések akár a politikai pártok komoly ellenfeleivé nőhetik ki magukat. Ez a napjainkban egyre kézzelfoghatóbbá váló tendencia összhangban van az EU fejlesztési politikájának új irányaival, melyek a központi, regionális, helyi és uniós kormányzati szervek, a magánszektor, valamint a helyi és országos szintủ civil szervezetek közötti együttmüködést, partnerséget hangsúlyozzák (Tóth 2005).

A civil szervezetek a regionális fejlesztés területén leggyakrabban a következő kihívásokkal és lehetőségekkel szembesülnek:

- konzultáció, képzés,

- a monitoring szervezeteiben való részvétel,

- a területfejlesztés irányító testületeiben történỏ részvétel,

- a fejlesztési források megszerzésének a lehetősége.

2005. december 31-én 27221 regisztrált civil szervezet volt Szlovákiában, mely közel 30\%-os emelkedést jelentett a 2003-2005 közti időszakban (1. táblázat). A civil szektor makrogazdasági szinten jelentős tényező: szolgáltatásaik összértéke, valamint önmagában a közösségi fejlesztés értéke azt mutatja, hogy a szektor nem megfelelő müködése, esetleges hanyatlása jelentős negatív hatással lenne a társa- 
Lelkes Gábor: A szlovákiai regionális fejlesztéspolitika s annak középtávú dél-szlovákiai határ menti vetülete az uniós támogatáspolitika tükrében. - Tér és Társadalom 22. évf. 2008/3. 151-184. p.

dalmi-gazdasági fejlödés egészére, ugyanis a nonprofit szervezetek tevékenysége meghatározó gazdasági hatásokat indukál.

A szlovákiai nonprofit szektor nagy várakozással tekintett az EU-csatlakozás elé (a fenti számbeli növekedés is ezt támasztja alá), hiszen a csatlakozás kapcsán számtalan olyan forrás nyílt meg számukra, melyek segítségével jelentős mértékben növelhették tevékenységük hatékonyságát és intenzitását. Az elvárások között fontos helyen szerepelt az is, hogy a fenti források végre lehetővé teszik a szervezetek hosszú távú és kiszámítható müködését ${ }^{5}$, illetve a mindenkori állami szereplök nem „támogatói”, hanem végre partneri kapcsolatba kerülnek a nonprofit szervezetekkel.

\section{TÁBLÁZAT}

Civil szervezetek jogi formáinak megoszlása 2002-2005 közt

(Division of Nonprofit Organizations by Legal Forms in Period 2002-2005)

\begin{tabular}{lrrrr}
\hline \multicolumn{1}{c}{ Jogi forma } & 2002 & 2003 & 2004 & 2005 \\
\hline Polgári társulások & 20803 & 20575 & 23789 & 25257 \\
Jótékonysági alap & 345 & 440 & 513 & 497 \\
Közhasznú szolgáltatásokat nyújtó & 215 & 397 & 831 & 1021 \\
Alapítvány & 553 & 249 & 305 & 325 \\
Nemzetközi szervezet & - & - & 122 & 121 \\
Összesen & 21916 & 21661 & 25560 & 27221 \\
\hline
\end{tabular}

Forrás: Slovensko (2006).

Az elmúlt négy év alatt a civil szervezetek hatékonysága és müködése javult (amit a források átlátható felhasználása követelt $\mathrm{meg}^{6}$ ), valamint beigazolódott, hogy a civil szervezetek a területfejlesztés lényeges szereplöinek tekinthetőek, mert

- a civil szervezetek jelentős része tapasztalatot szerzett a pályázati rendszerekben,

- a területfejlesztés feladatainak jelentős része állami, önkormányzati feladatként nem végezhetö el;

- a civil szervezetek képesek alternatív források felkutatására és megszerzésére megfelelö állami, önkormányzati együttmüködés esetén;

- képesek meggyőzni, bevonni és mozgósítani a lakosságot a területfejlesztési programokban történő hatékony és öntevékeny részvételre;

- az EU fejlesztési támogatásainak jelentősebb része nem szerezhetö meg a civil szervezetek nélkül;

- az EU fejlesztési programjainak egyre nagyobb része az alulról építkezés elve szerint épül fel, amely a civil szervezetek domináns részvételét feltételezi;

- a civil szervezetek érdekeltek a területfejlesztési programokban történő sikeres részvételben, mert ez számukra müködési forrást és legitimációt biztosíthat a helyi társadalomban.

Az elmúlt években az uniós források mellett lényegesen nőtt a civil szervezeteknek nyújtott anyagi támogatás a kerületi és a települési önkormányzatok részéröl, 
Lelkes Gábor: A szlovákiai regionális fejlesztéspolitika s annak középtávú dél-szlovákiai határ menti vetülete az uniós támogatáspolitika tükrében. - Tér és Társadalom 22. évf. 2008/3. 151-184. p.

TÉT XXII. évf. 2008 - 3 A szlovákiai regionális fejlesztéspolitika...159

annak ellenére, hogy a közszféra és a civil szféra közti partnerségi együttmüködés még nem érte el a kívánt szintet.

A dél-szlovákiai tér fejlesztésének civil szereplöi közt legmeghatározóbb szereppel a Fórum Intézet bir, amely a Fórum Kisebbségkutató Intézet, a Fórum Információs Központ és a Fórum Régiófejlesztési Központ konzorciumából áll, s mely konzorcium célja a magyarlakta régiók fejlesztési lehetöségeinek feltárása, az ágazatok közti partneri együttmüködés és a projektum menedzsment elösegítése a délszlovákiai régiók fejlődési potenciáljának kihasználása és a magyar kisebbség társadalmi-gazdasági gyarapodásának támogatása érdekében.

A Fórum Intézet a 10 éves fennállása alatt számos projekttel segítette a szlovákiai magyar közösség fejlődését, amelyek közt kiemelendö a szlovákiai magyar nonprofit intézményrendszer feltérképezése és megszervezése a modern kor követelményrendszerének megfelelően, felismerve a civil szervezetek regionális fejlesztésben betöltött jelentős szerepét (a szlovákiai magyar regionális civil társadalom alacsony fejlettséget mutatott a regionális fejlesztési aktivitások terén egészen a kilencvenes évek végéig, a Fórum Intézet fellépéséig).

A Fórum Intézet ezen tevékenységével kapcsolatosan megemlítendő a Nonprofit 1x1 c. kiadvány, mely a megjelenését követően eltelt fél évtized óta máig a szlovákiai magyar civil szervezetek "Bibliájának"számít. A Nonprofit 1x1 c. kötet a szervezet megalakulásától, mindennapi gondjain és teendőin keresztül, egészen a megszüntéig kíséri nyomon az intézmény életét (bemutatva a jól szervezett tevékenység, a hosszú távú stratégiai tervezés, a múködő belső és külső kommunikáció, a csapatmunka, az adománygyűjjtés, a megfelelő gazdálkodás sok-sok eszköztárát).

A Nonprofit 1xl kiadvánnyal egy időben jelentetett meg a Fórum Intézet egy további nagyon fontos és hiánypótló kiadványt a szlovákiai magyar civil szféra számára, mégpedig A szlovákiai magyar szervezetek adattára c. kötetet. Ezen kiadvány több mint 650 szlovákiai magyar nonprofit szervezet adatait tartalmazza, kiegészítve a Szlovákiában, illetve Szlovákiából elérhető adományozó intézmények programjaival és elérhetőségi adataival. A kötetben nagyon részletes adománygyüjtési útmutató is található, amely a pályázásban próbál segíteni a szervezeteknek.

\section{Egyéb szereplök}

Az eddig említett szervezetek és intézmények mellett számos további szervezet müködik, amelyek aktívan részt vesznek a helyi és regionális fejlesztési projektumok megtervezésében és végrehajtásában, ill. szorosan együttmüködnek a fent említett intézményekkel, nonprofit szervezetekkel, vállalkozókkal és önkormányzatokkal.

Az elmúlt évtized kisebb-nagyobb intézményi szereplői közt említést kell tenni egy jelentősebb intézményi hálózatról, amelyet a magyarországi Új Kézfogás Közalapítvánnyal (UKKA) szerződéses kapcsolatban álló vállalkozásfejlesztési központok alkottak, s mely központok az UKKA programjait képviselték megbízásos alapon ${ }^{7}$ több mint fél évtizeden keresztül. (Az UKKA 2006 decemberében megszünt, felada- 
Lelkes Gábor: A szlovákiai regionális fejlesztéspolitika s annak középtávú dél-szlovákiai határ menti vetülete az uniós támogatáspolitika tükrében. - Tér és Társadalom 22. évf. 2008/3. 151-184. p.

tait 2007-töl a Corvinus Támogatásközvetitő Zrt. vette át, mely intézmény némileg módosított célkitüzések mellet tovább halad majd az UKKA által megkezdett úton.)

Az UKKA programjainak célja a szlovákiai magyar közösség gazdasági helyzetének javitása, a szlovákiai magyar kis- és közepes vállalkozások müködési feltételeinek javítása, a szlovákiai magyar vállalkozások hazai és nemzetközi piacra jutási képességének növelés, a tulajdonszerzéshez támogatás nyújtása, a tudásalapú szlovákiai magyar társadalom létrejöttének és a technológia transzfernek az elösegítése, addicionális források bevonásának elösegítése (különös tekintettel az EUforrásokra) a szlovákiai magyar társadalom fejlődése érdekében, valamint a határ menti magyarlakta régiók és Magyarország közötti gazdasági együttműködés elősegítése volt. Az UKKA támogatási rendszerénél a határon túli magyarság helyben maradása és boldogulása érdekében az alábbi prioritásokat tartotta szem előtt:

- versenyképesség elősegitése,

- közösségi hatás erősítése,

- munkahelyteremtés,

- törekvés a hozzáférhetö források bevonásának összehangolására,

- intézményi rendszer építése.

Az UKKA által megvalósított projektek közt kiemelendỏ egy innovatív kutatásfejlesztési-képzési projektum, amely 2003-2004 között valósult meg, s célja a délszlovákiai fejlesztési erőforrások feltárása, a lehetséges stratégiai kitörési pontok meghatározása és területfejlesztési szakemberképzés volt. A projektum első szakaszában fiatal szlovákiai magyar területfejlesztési szakemberek szakmai továbbképzésen vettek részt a Magyar Tudományos Akadémia Regionális Kutatások Központjában (MTA RKK), majd az MTA RKK munkatársaival közösen keresték Szlovákia, s azon belül Dél-Szlovákia térszerkezetében rejlö fejlődési irányvonalakat, fejlesztési lehetőségeket. A kutatások eredményeképpen feltárt hatalmas ismeretanyag - mely alapot kínál települések és kistérségek stratégiai területfejlesztési programjainak elkészítéséhez - Dél-Szlovákia címmel megjelent kiadványban vált hozzáférhetővé a nagyközönség és a területfejlesztésben érintett szakemberek számára (a kötet az MTA RKK és a Dialóg Campus könyvkiadó gondozásában jelent meg 2004 őszén).

\section{Térségfejlesztési keretek}

A regionális fejlesztés kereteit Szlovákiában a regionális fejlesztés támogatásáról szóló 503/2001 T.t. számú törvény határozza meg, mely 2002 január 1-jén lépett hatályba. Ezen törvény, mely az ország területfejlesztési politikájában mérföldkőnek számit, a regionális fejlesztéssel kapcsolatos támogatási célokat az alábbi négy pontban fogalmazza meg:

- a Szlovák Köztársaság kiegyenlített gazdasági és szociális fejlödésének a biztosítása,

- a régiók közt fennálló gazdasági és szociális fejlettségbeli különbségek mérséklése és megszüntetése, 
Lelkes Gábor: A szlovákiai regionális fejlesztéspolitika s annak középtávú dél-szlovákiai határ menti vetülete az uniós támogatáspolitika tükrében. - Tér és Társadalom 22. évf. 2008/3. 151-184. p.

- az alacsony gazdasági teljesítményü és életszínvonalat biztositó régiók újabb keletkezésének a megakadályozása,

- a régiók tartósan fenntartható gazdasági és szociális fejlődésének biztosítása.

Az 503/2001-es törvény a regionális fejlesztéssel kapcsolatban az alábbi támogatási területeket nevezte meg prioritásként:

- a gazdaság és a vállalkozói környezet támogatása azok termelési kapacitásának növekedése érdekében, a gazdasági szerkezet javítása, új munkahelyek teremtése, a veszélyeztetett munkahelyek stabilizálása;

- a humán eröforrás fejlesztése annak érdekében, hogy a regionális munkaerőpiacon a kereslet és a kínálat közt egyensúly alakuljon ki, a nők és a férfiak egyenlő munkavállalási esélyének a biztosítása;

- a regionális fejlődést elősegitő kutatások tartós fejlesztése, az új technológiák és innovációk bevezetésének hangsúlyozott támogatása;

- az államok közti, a határon átívelő és az interregionális együttmüködések támogatása a regionális fejlesztés terén a régió tartósan fenntartható fejlődése érdekében;

- az idegenforgalom fejlesztése;

- a régió szociális infrastruktúrájának fejlesztése;

- a régió technikai infrastruktúrájának fejlesztése;

- a kultúra, kulturális tevékenységek és szolgáltatások fejlesztésének támogatása, beleértve a müvészeti tevékenységeket, a kulturális örökség ápolását, a müemlékek felújítását és revitalizációját;

- a régió szolgáltatási színvonalának fejlesztése;

- az életkörnyezet javítása és fejlesztése, az azt károsító tényezők minimalizálása;

- a természeti erőforrások hatékony felhasználásának támogatása.

A fent említett törvény kimondja, hogy a regionális fejlesztés elsỏ számú célterületeit a szlovák kormány határozza meg a regionális fejlesztési minisztérium ajánlása alapján, amely a támogatott régiók kiválasztásánál az alábbi két szempontot veszi figyelembe:

- gazdaságilag gyenge régiók, melyek gazdasági és fejlettségi szintje elmarad az országos átlagtól, amit elsősorban az alábbi mutatók értéke jelöl: a munkaerőpiac, a gazdaság szerkezete és termelési szintje, a kerületi önkormányzatok, a községek és a lakosság bevétele, valamint a településsủrüség,

- gazdaságilag kedvezötlen szerkezetü régiók, melyekben a szerkezetváltás negatív következményei felhalmozódtak, melynek következtében az ágazatok teljesítménye és a vállalkozások száma csökken, míg a munkanélküliség növekszik.

A tárgyalt törvény kimondja, hogy az EU alapjaiból folyósított támogatási eszközöknél a regionális fejlesztés érdekében a régiók fejlettségi szintje a NUTS2 szinten $^{8}$ értékelődik, $\mathrm{s}$ azon területek minősülnek gazdaságilag gyengének, amelyekben a bruttó hazai termék (GDP) egy lakosra eső vásárlóerőn mért paritása nem éri el az EU hasonló mutatójának 75\%-át az elmúlt 3 év alatt. 
Lelkes Gábor: A szlovákiai regionális fejlesztéspolitika s annak középtávú dél-szlovákiai határ menti vetülete az uniós támogatáspolitika tükrében. - Tér és Társadalom 22. évf. 2008/3. 151-184. p.

\section{4. ÁBRA}

A Regionális Fejlesztések Támogatásáról szóló 503/2001 T.t. számú törvény által meghatározott területi megközelitésü stratégiai alapdokumentumok

(Strategical Development Documents Based on the Act No. 503/2001 about Supporting Regional Development)

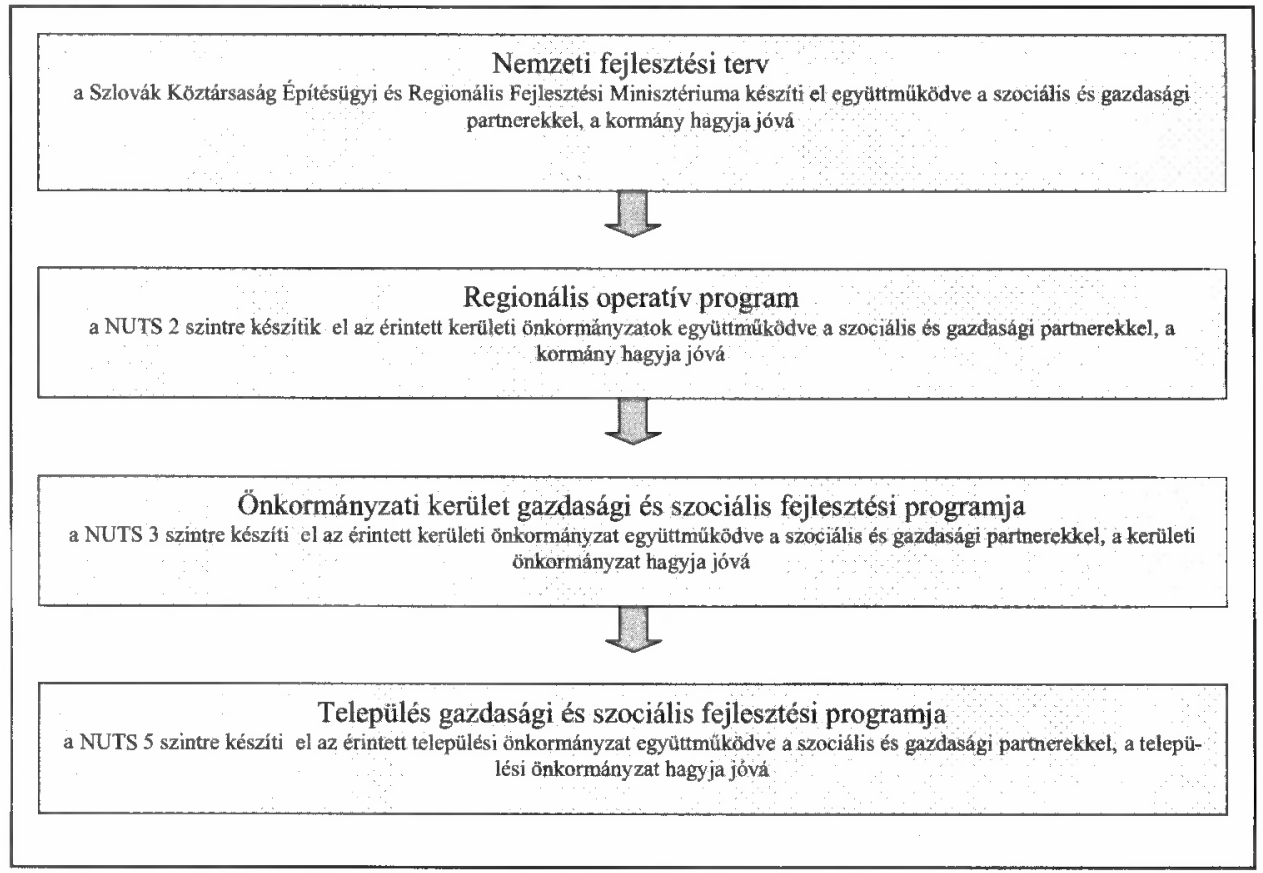

Forrás: Saját szerkesztés.

A 503/2001 T.t. számú törvény továbbá tartalmazza, hogy a regionális fejlesztés támogatása a programozás keretén belül az alábbi dokumentumok alapján megy végbe: nemzeti fejlesztési terv, közösségi támogatási keret, operatív programok (regionális operativ programok, ágazati operatív programok), önkormányzati kerületek gazdasági és szociális fejlödésének programjai, községek gazdasági és szociális fejlödésének programjai, egységes programdokumentumok, Kohéziós Alap stratégiai programdokumentuma, Európai Közösségek Kezdeményezése program (4. ábra).

A fentiekben tárgyalt törvény mellett a regionális fejlesztés második legjelentősebb keretelemének a Szlovákia Területfejlesztési Koncepciója 2001 (SZTK 2001) stratégiai dokumentum számít, amely felvázolja, illetve kijelöli a területfejlesztési intézkedéseket - az ország területfejlesztési politikájának célkitüzéseit, elveit és prioritás-rendszerét, megteremtve a területi szempontok konzekvens érvényesítésének lehetőségét, mind az ágazati szakpolitikák, mind az országos és területi programok kidolgozásában (5. ábra). A kiemelt stratégiai célok szinte mindegyikére jellemzó, hogy az intézkedések megvalósítása hosszabb idősíkot igényel. Az SZTK 
Lelkes Gábor: A szlovákiai regionális fejlesztéspolitika s annak középtávú dél-szlovákiai határ menti vetülete az uniós támogatáspolitika tükrében. - Tér és Társadalom 22. évf. 2008/3. 151-184. p.

TÉT XXII. évf. 2008 — 3 A szlovákiai regionális fejlesztéspolitika...163

2001 által felvázolt koncepció kötelező érvényü intézkedéseit az 528/2002 számú kormányrendelet tartalmazza.

\section{5. ÁBRA}

Szlovákia jövőbeni társadalmi-gazdasági poziciójảnak viziója az európai térszerkezetben várható fejlödési folyamatok alapján

(Future Social and Economic Position of Slovakia Regarding Development Processes in the European Space Structure)

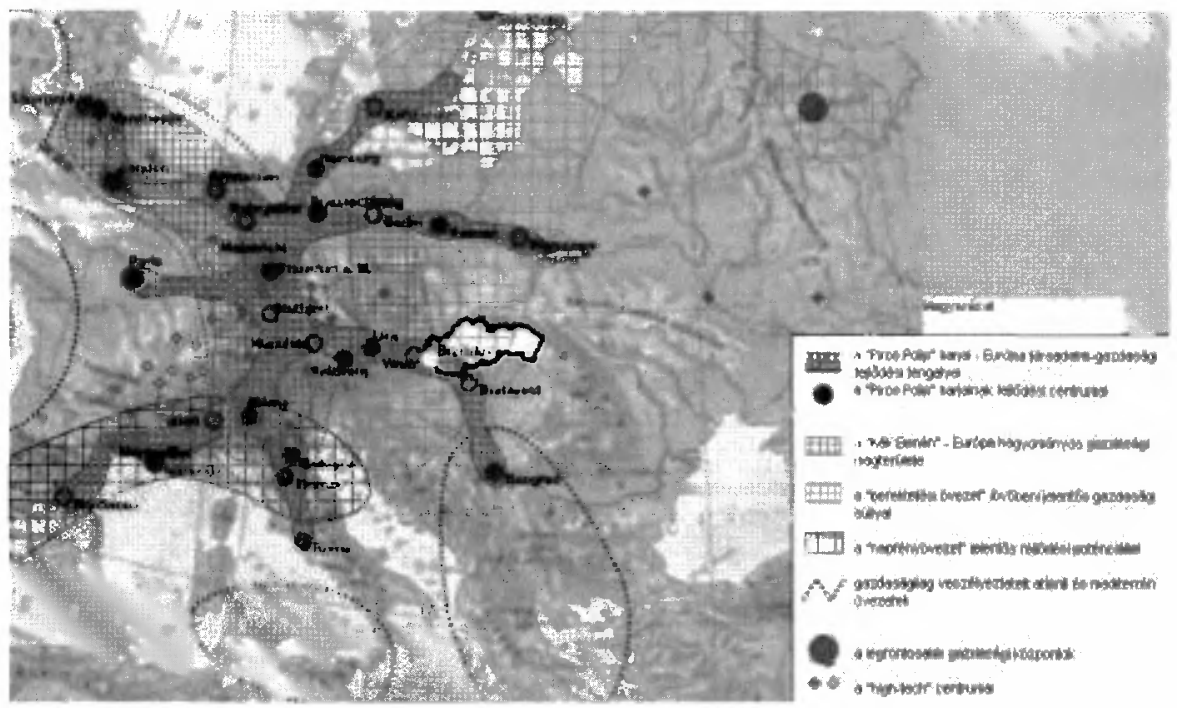

Forrás: Szlovákia Területfejlesztési Koncepciója (2001).

Az SZTK (2001) nemzetközi viszonylatban az alábbi térségfejlesztési prioritásokat fogalmazta meg:

- kapcsolatok erősítése az egyik legjelentösebb európai urbanisztikai tengelyre Stuttgard-Ulm-München-Salzburg/Linz-Bécs/Pozsony-Budapest-Belgrád, mindenekelőtt Pozsony térségében és a Duna mentén,

- települési központok fejlesztése a Katowice-Bécs és Katowice-Budapest tengelyek mentén,

- települési kapcsolatok erősítése a Vág menti települési sáv és a vele párhuzamosan futó csehországi települési sáv közt,

- Pozsony-Nagyszombat települési központ fejlesztése az európai jelentőségü Bécs-Pozsony-Győr agglomeráció részeként,

- Kassa-Eperjes települési központ fejlesztése, mint a Kárpátok eurorégió centruma,

- nemzetközi hálózati egyuittmúködések létrehozása a városok, régiók és a területi fejlesztésben érdekelt többi intézmények közt, felhasználva a települések és települési rendszerek euroregionális és határon átnyúló kapcsolatait,

- a multimodális tengelyek mentén fekvő települések fejlesztése, legföképp az észak-dél és kelet-nyugat irányú tengelyek metszéspontjaiban találhatókat. 
Lelkes Gábor: A szlovákiai regionális fejlesztéspolitika s annak középtávú dél-szlovákiai határ menti vetülete az uniós támogatáspolitika tükrében. - Tér és Társadalom 22. évf. 2008/3. 151-184. p.

Országos viszonylatban az SZTK 2001 az alábbi térségfejlesztési prioritásokat tartalmazza (6. ábra):

- Kassa-Eperjes agglomeráció fejlesztése kapcsolatban a NagymihályVarannó-Homonna települési központtal és összeköttetésben az Észak-Vág menti és dél-szlovákiai fejlesztési tengelyekkel,

- nemzetközi viszonylatokban versenyképes településszerkezet kialakítása, Zsolna-Turócszentmárton, Besztercebánya-Zólyom, Losonc-Rimaszombat települési központok létrehozása (a Losonc-Rimaszombat települési központ lényeges szereppel bír majd az egész középdél-szlovákiai tér fejlesztésében),

- Pozsony-Nagyszombat-Nyitra települési központ fejlesztése kötődésben az európai jelentőségủ agglomerációk policentrikus rendszeréhez,

- Pozsony, mint európai specifikus központ fejlesztése,

- Kassa, mint nemzetközi központ és mint a Kárpátok eurorégió centrumának fejlesztése,

- az első kategória első alcsoport kategóriájú centrumok fejlesztése: Besztercebánya, Nyitra, Eperjes, Zsolna,

- az első kategória második alcsoport kategóriájú centrumok fejlesztése: Nagyszombat, Trencsén, Turócszentmárton, Poprád,

- a második kategória első alcsoport kategóriájú centrumok fejlesztése: Dunaszerdahely, Bártfa, Komárom, Liptószentmiklós, Nagymihály, Pőstyén, Privigye, Igló, Csaca, Homonna, Léva, Losonc, Érsekújvár, Vágbeszterce, Rózsahegy, Zólyom,

- az első kategóriảjú települési központok fejlesztése:

- Pozsony-Nagyszombat települési központ, mint a legjelentősebb szlovákiai agglomeráció, mely európai jelentőségü;

- az első kategóriájú fejlesztési tengelyek támogatása:

- Vág menti fejlesztési tengely (Pozsony-Nagyszomba-Trencsén-Zsolna),

- zsolnai-tátraalji fejlesztési tengely (Zsolna-Turócszentmárton-PoprádEperjes),

- zsolnai-kiszucai fejlesztési tengely (Zsolna-Csaca-szlovák-cseh határ),

- kassai-eperjesi fejlesztési tengely (Eperjes-Kassa-szlovák-magyar határ),

- nyitrai- Vág menti fejlesztési tengely (Nagyszombat-NyitraGaramszentkereszt-Zólyom),

- zólyomi-turóci fejlesztési tengely (Zólyom-BesztercebányaTurócszentmárton),

- zólyomi-dél-szlovákiai fejlesztési tengely (Zólyom-LosoncRimaszombat-Rozsnyó-Kassa),

- kelet-szlovákiai fejlesztési tengely (Kassa-Nagymihály-Szobráncszlovák-ukrán határ),

- erdőháti fejlesztési tengely (Pozsony-Malacka-szlovák-cseh határ);

- a második kategóriájú fejlesztési tengelyek támogatása:

- csallóközi fejlesztési tengely (Pozsony-Dunaszerdahely), 
Lelkes Gábor: A szlovákiai regionális fejlesztéspolitika s annak középtávú dél-szlovákiai határ menti vetülete az uniós támogatáspolitika tükrében. - Tér és Társadalom 22. évf. 2008/3. 151-184. p.

TÉT XXII. évf. 2008 『 3 A szlovákiai regionális fejlesztéspolitika...165

- Nyitra menti fejlesztési tengely (Trencsén-Nagytapolcsány-NyitraÉrsekújvár-Komárom),

- Garam menti fejlesztési tengely (Tolmács-Léva-Zselíz-Párkány),

- dél-szlovákiai fejlesztési tengely (Érsekújvár-Zselíz-Ipolyság-Losonc),

- nógrádi fejlesztési tengely (Losonc-Fülek-szlovák-magyar határ),

- sárosi fejlesztési tengely (Eperjes-Bártfa),

- liptói-árvai fejlesztési tengely (Rózsahegy-Alsókubín-Trsztenászlovák-lengyel határ).

\section{6. ÁBRA}

Szlovákia fejlesztési tengelyei az SZTK (2001) alapján

(Development Axes in Slovakia Regarding the Strategy Conception of the Space Development Policy of Slovakia, 2001)
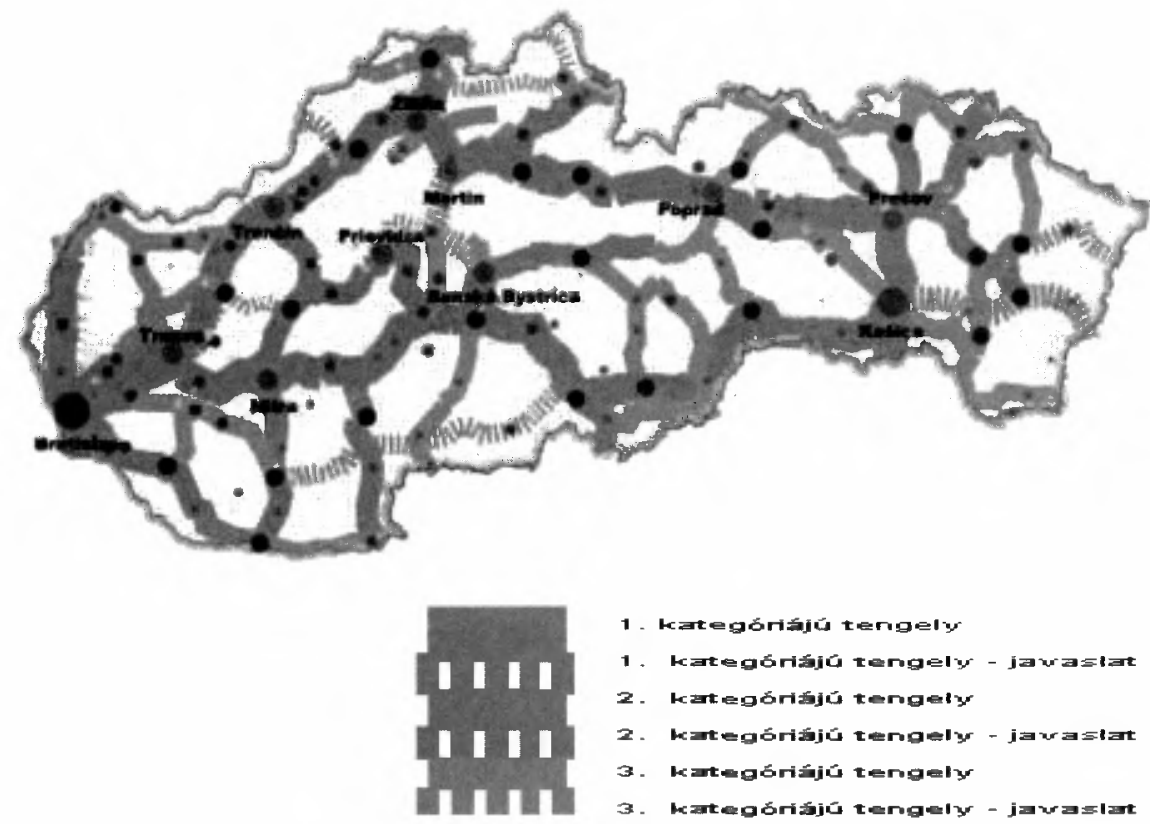

Forrás: Szlovákia Területfejlesztési Koncepciója (2001).

\section{A szlovák-magyar határ megjelenése a határ menti önkormányzati kerületek gazdasági és szociális fejlesztési programjaiban}

Pozsonyi kerület

A gazdasági és szociális fejlesztési programban a magyar-szlovák határ menti együttmüködés, mint lehetőség/eszköz a regionális fejlesztésre, konkrétan nincs megemlítve. A programdokumentum azonban a kerület 15 prioritása közé sorolta a 
Lelkes Gábor: A szlovákiai regionális fejlesztéspolitika s annak középtávú dél-szlovákiai határ menti vetülete az uniós támogatáspolitika tükrében. - Tér és Társadalom 22. évf. 2008/3. 151-184. p.

nemzetközi és a határon átnyúló együttmủködéseket, mely prioritás két intézkedésre van bontva: határon átnyúló partnerség-építés a szomszédos országokkal, valamint feltételek megteremtése pozsonyi székhellyel müködö nemzetközi intézmények létrehozására.

\section{Nagyszombati kerület}

A gazdasági és szociális fejlesztési program a magyar-szlovák határ menti együttmúködést alprioritásként kezeli a „Határ menti, transznacionális és interregionális együttmüködés" prioritás keretén belül, részletesen a határmentiséget, mint lehetöséget/eszközt a regionális fejlesztésre. A magyar-szlovák határ menti együttmüködést három alprioritásban határozza meg (melyek egészen az intézkedések és aktivitások szintjére vannak szétbontva):

- a határ menti régiók szociális és gazdasági együttmúködése - mely az alábbi intézkedéseket öleli fel: kis- és középvállalkozások együttmüködése, városok és falvak együttmüködése, határon átnyúló intézményi együttmúködés, vidékfejlesztés;

- határon átnyúló infrastruktúra - mely az alábbi intézkedéseket öleli fel: environmentális befektetések, együttmüködés a természetvédelemben, közlekedési és telekommunikációs infrastruktúra fejlesztése;

- határon átnyúló programozás támogatása.

\section{Nyitrai kerület}

A gazdasági és szociális fejlesztési programban a kerület számára meghatározott hét fejlesztési stratégiai terület egyike a „Nemzetközi együttműködés”, azonban a szlovák-magyar határ menti együttmüködés konkrétan nincs megemlítve az emlitett területen. A nevezett stratégiai területen belül mindössze árnyalt megfogalmazás szintjén kerül megemlítésre a Duna menti együttmúködés erősítése (elsősorban gazdasági területen). A szlovák-magyar határ felmerül több szakpolitikai kérdésben:

- Garamszentkereszt-Léva-Párkány gyorsforgalmi út és erre kapcsolódva Párkánynál egy új dunai híd megépítése,

- a kerület idegenforgalmi látványosságainak népszerúsítése magyar nyelven.

\section{Besztercebányai kerület}

A gazdasági és szociális fejlesztési programban a kerület fejlesztési prioritásai összesen hét - között nem szerepel sem a nemzetközi együttmüködés, sem a határ menti együttmúködés. A szlovák-magyar határ érintőlegesen egy-egy szakpolitikai célkitüzés keretén belül van megemlítve:

- szlovák-magyar határ-Ipolyság-Zólyom vasútvonal modernizálása,

- a határon átnyúló munkaerőpiac létrehozása,

- az idegenforgalmi fejlesztések során szoros kapcsolat Magyarországgal. 
Lelkes Gábor: A szlovákiai regionális fejlesztéspolitika s annak középtávú dél-szlovákiai határ menti vetülete az uniós támogatáspolitika tükrében. - Tér és Társadalom 22. évf. 2008/3. 151-184. p.

TÉT XXII. évf. 2008 『 3

A szlovákiai regionális fejlesztéspolitika...167

\section{Kassai kerület}

A gazdasági és szociális fejlesztési programban a kerület öt stratégiai fejlesztési területe között nem szerepel sem a nemzetközi együittmüködés, sem a határ menti együttmüködés. A szlovák-magyar határ érintőlegesen egy-egy szakpolitikai célkitüzés keretén belül van megemlítve:

- a „Mezögazdaság és vidékfejlesztés” stratégiai fejlesztési területnél említésre kerül, a tokaji borvidék fejlesztésénél fontos a magyarországi tokaji borvidékkel való együttműködés,

- a „Közlekedés és telekommunikáció” stratégiai fejlesztési területnél említésre kerül Kassa-Miskolc gyorsforgalmi útszakasz megépitésének szükségessége, valamint a hajózási feltételek javítása a Tiszán,

- a „Szociális töke és intézményi együttmúködés megerősítése" stratégiai fejlesztési területnél említésre kerül a szlovák-magyar határ menti eurorégiók fontos szerepe a regionális fejlesztések terén,

- a „Kis- és középvállalkozások gazdasági aktivitásának növelése” stratégiai fejlesztési területnél kiemelésre kerül, hogy a határ menti területek idegenforgalmi fejlesztésénél fontos az együttmüködés és koordináció a szomszédos régiók idegenforgalmi szereplöivel.

\section{Az uniós támogatási programok}

Az Európai Unió deklarált célja az egyes országok és régiók között fennálló fejlettségi különbségek mérséklése és a kevésbé fejlett térségek felzárkóztatásának elősegítése. E cél érdekében az EU forrásokat biztosít, melyek többsége az alábbi három nagyobb csoportba sorolható:

- elöcsatlakozási alapok,

- Strukturális Alapok, Kohéziós Alap és egyéb uniós alapok,

- közösségi kezdeményezések.

Az elöcsatlakozási alapok azon pénzügyi eszközök együttes elnevezése, amelyeket az Európai Unió a társult országok csatlakozásra való felkészülésének támogatására állított fel. 1990-töl kezdődően a Phare volt az az uniós támogatási forma, amely Szlovákia társadalmi-gazdasági fejlesztéséhez elöször adott pénzügyi segítséget, majd a későbbiekben további két uniós forrás - ISPA ${ }^{10}, \mathrm{SAPARD}^{11}$ - is segítette az ország regionális fejlesztését és a területfejlesztést intézményesíteni. Szlovákia az EU-csatlakozást megelözöen az elöcsatlakozási alapokból mintegy 1 milliárd euró támogatást kapott olyan alapvető problémák megoldására, mint a közlekedési és környezetvédelmi infrastruktúra, a munkahelyek teremtése, a határ menti együttmüködés - a határ menti területek gazdasági és kulturális kapcsolatainak erösítése és a területfejlesztési elképzelések kölcsönös összehangolása -, de jelentős összegekkel támogatták például a vidéken élö gazdáknak a mezőgazdasági gépek vásárlását is. 
Lelkes Gábor: A szlovákiai regionális fejlesztéspolitika s annak középtávú dél-szlovákiai határ menti vetülete az uniós támogatáspolitika tükrében. - Tér és Társadalom 22. évf. 2008/3. 151-184. p.

168 Lelkes Gábor

TÉT XXII. évf. 2008 - 3

Az ország uniós csatlakozását követően a 2004-2006 rövidített programozási időszakban a területfejlesztési politika egyik alapdokumentuma a Nemzeti Fejlesztési Terv lett. A Nemzeti Fejlesztési Terv komplex áttekintést nyújt az 1. célkitüzés ${ }^{12}$ szerint támogatott szlovákiai régiókról. A Nemzeti Fejlesztési Terv taglalja továbbá az egyes régiók szükségleteit, a fejlődésüket gátló tényezőket, csakúgy mint azt, hogy ezeken miként lehet az egyes fejlesztési stratégiákat alkalmazva túllépni (különös tekintettel a munkanélküliséget csökkentő nemzeti stratégiákra). A dokumentum stratégiai célként azt fogalmazta meg, hogy a tartósan fenntartható fejlödés dinamikája mellett az ország 2006-ban meghaladja az egy fỏre eső GDP-ben az uniós átlag 54\%-át. A Nemzeti Fejlesztési Terv az alábbi négy prioritást fogalmazta meg:

1) az ipar és szolgáltatások versenyképességének a növelése,

2) a szakképzett és rugalmas munkaerőn alapuló foglalkoztatottság növelése,

3) multifunkciós mezőgazdaság és vidékfejlesztés,

4) a közlekedési, a környezeti és a települési infrastruktúra fejlesztése.

A Nemzeti Fejlesztési Tervben megfogalmazott négy prioritás és a technikai segítségnyújtás együttes költsége a 2004-2006 időszakban 1682,15 millió euró volt (2. táblázat). Ezen összegből az ERDF (European Regional Development Fund Európai Regionális Fejlesztési Alap ${ }^{13}$ ) részesedése 24,65\% (414,64M euró), az ESF (European Social Fund - Európai Szociális Alap) ${ }^{14}$ részesedése 15,11\% (254,19M euró), az EAGGF (European Agricultural Guidance and Guarantee Fund - Európai Mezőgazdasági Orientációs és Garanciaalap) ${ }^{15}$ részesedése 14,69\% (247,03M euró), míg a FIFG (Financial Instrument for Fisheries Guidance - Halászati Orientációs Pénzügyi Eszköz) ${ }^{16}$ részesedése $0,30 \%(5,04 \mathrm{M}$ euró) volt. A Strukturális Alapok összesen a kiadások 54,75\%-át tették ki, ami 920,9 millió euró hozzájárulást jelentett. Az összkiadásoknak 19,97\%-át az állami költségvetés állta, míg a községi önkormányzatok által nyújtott összeg a kiadások 1,79\%-át tette ki ( 30,18 millió euró). A magánszféra hozzájárulása összesen 395,17 millió eurót tett ki $(23,49 \%)$.

A Nemzeti Fejlesztési Tervben a prioritások közötti forrásmegosztás arányai így mutattak:

- az ipar és a szolgáltatások versenyképességének a növelése - 15,71\%,

- a szakképzett és rugalmas munkaerőn alapuló foglalkoztatottság növelése $19,75 \%$,

- a multifunkciós mezögazdaság és vidékfejlesztés - 36,48\%,

- a közlekedési, a környezeti és a települési infrastruktúra fejlesztése - 26,88\%.

A Nemzeti Fejlesztési Terv kidolgozását követően a benne meghatározott specifikus célok megvalósításának kapcsán kerültek kidolgozásra az ágazati operatív programok (Agrảr- és Vidékfejlesztés Operativ Program ${ }^{17}$, Humán Eröforrás Operativ Program $^{18}$, Ipar és Szolgáltatások Operatív Program ${ }^{19}$ ) és az Alap Infrastruktúra Operatív Program ${ }^{20}$ (mely az ország infrastrukturálisan elmaradott és az 1. célkitüzésbe tartozó 7 kerületének a közlekedési, a környezeti és a települési infrastruktúrájának fejlesztését tervező programdokumentum). A kitüzött célok elérésének céljából mind a négy operatív program prioritásokat állapít meg, illetve egy sor saját 
Lelkes Gábor: A szlovákiai regionális fejlesztéspolitika s annak középtávú dél-szlovákiai határ menti vetülete az uniós támogatáspolitika tükrében. - Tér és Társadalom 22. évf. 2008/3. 151-184. p.

TÉT XXII. évf. 2008 - 3 A szlovákiai regionális fejlesztéspolitika...169

intézkedés megtételérỏl gondoskodik. A program-kiegészítőkben aztán ezen intézkedéseket egészen a tevékenységek szintjére bontották le, mégpedig pontosan meghatározott:

- támogatási csoportokkal és összegekkel,

- lehetséges kedvezményezettekkel,

- célcsoportokkal.

\section{TÁBLÁZAT}

A Nemzeti Fejlesztési Terv prioritásai és költségvetése az uniós forrásokat illetöen (millió euró)

(Priorities and Budget Allocations of National Development Plan)

\begin{tabular}{|c|c|c|c|c|c|c|c|}
\hline \multirow[b]{2}{*}{ Prioritás, időszak } & \multirow{2}{*}{$\begin{array}{c}\text { Össz- } \\
\text { költség- } \\
\text { vetés }\end{array}$} & \multicolumn{5}{|c|}{ Európai Közösségek } & \multirow{2}{*}{$\begin{array}{c}\text { Kohéziós } \\
\text { Alap }\end{array}$} \\
\hline & & $\begin{array}{l}\text { Össze- } \\
\text { sen }\end{array}$ & $E R D F$ & $E S F$ & $E A G G F$ & FIFG & \\
\hline $\begin{array}{l}\text { Prioritás 1- Ipar és } \\
\text { Szolgáltatások } \\
\text { Operatív Program }\end{array}$ & 264,29 & 131,09 & 131,09 & 0,00 & 0,00 & 0,00 & 0,00 \\
\hline $\begin{array}{l}\text { Prioritás } 2-\text { Hu- } \\
\text { mán Erőforrás } \\
\text { Operatív Program }\end{array}$ & 332,15 & 249,11 & 0,00 & 249,11 & 0,00 & 0,00 & 0,00 \\
\hline $\begin{array}{l}\text { Prioritás 3- Agrár- } \\
\text { és Vidékfejlesztés } \\
\text { Operatív Program }\end{array}$ & 613,61 & 250,56 & 0,00 & 0,00 & 245,52 & 5,04 & 0,00 \\
\hline $\begin{array}{l}\text { Prioritás } 4 \text { - Alap } \\
\text { Infrastruktúra } \\
\text { Operatív Program }\end{array}$ & 452,11 & 275,26 & 275,26 & 0,00 & 0,00 & 0,00 & 509,70 \\
\hline $\begin{array}{l}\text { Technikai segit- } \\
\text { ségnyújtás }\end{array}$ & 19,99 & 14,88 & 8,29 & 5,08 & 1,51 & 0,00 & 0,00 \\
\hline Összesen & 1682,15 & 920,90 & 414,64 & 254,19 & 247,03 & 5,04 & 509,70 \\
\hline
\end{tabular}

Forrás: Národný rozvojový plán (2003).

Az 1260/1999/EK tanácsi rendelet 4. cikkelyének rendelkezéseivel, illetve az Európa Bizottság egyéb követelményeivel összhangban a SZK Építésügyi és Régiófejlesztési Minisztériuma meghatározta a Pozsonyi kerület (NUTS2) azon térségeit, amelyek eleget tesznek a 2 . célkitüzés kategóriájába való besorolás követelményeinek. A fentiek szerint kialakított régióba a Malackai, a Bazini és a Szenci járás egyes területei, illetve a Dunacsúni, a Horvátjárfalui, az Oroszvári, a Pozsonyszőllösi és a Pozsonybesztercei városrészek lettek besorolva. Ez a Pozsonyi kerület teljes területének 28,82\%-át teszi ki. A 2. célkitúzés hatálya alá tartozó régió fejlesztési stratégiájának alapját elsősorban olyan célok képezik, mint a térségen belüli gazdasági tevékenység diverzifikálása, a fejlesztési erőforrások lehető leghatékonyabb kihasználása, illetve az infrastruktúra fejlesztése. A fent lehatárolt területeken az utóbbi célok az Egységes Programdokumentum Pozsony 2. célkitüzés programdokumentum alapján történtek a 2004-2006 időszakban, míg az adott régió humán- 
Lelkes Gábor: A szlovákiai regionális fejlesztéspolitika s annak középtávú dél-szlovákiai határ menti vetülete az uniós támogatáspolitika tükrében. - Tér és Társadalom 22. évf. 2008/3. 151-184. p.

eröforrás fejlesztésének kereteit az Egységes Programdokumentum Pozsony 3. célkitüzés programdokumentum adta meg.

A Strukturális Alapok mellett a 2004-2006 közti időszakban a Kohéziós Alap forrásai is jelentősen hozzájárultak az ország egyes régióinak a fejlődéséhez, a közlekedési és a környezetvédelmi infrastrukturális beruházásoknak köszönhetően - melyek a Kohéziós Alap által alkalmazott elv alapján nagy költségvetésủek (egy beruházás költségvetésének el kell érnie legalább a 10 millió eurót ${ }^{21}$ ), valamint a közlekedési hálózat fejlesztését illetően a projektumnak az európai kontinens kohézióját elösegítő transzeurópai hálózatok fejlesztéséhez kell hozzájárulnia.

\section{TÁBLÁZAT}

A Kohéziós Alapból megvalósitott közlekedési beruházások 2004-2006 közt (Investments into Transport Infrastructure from Cohesion Fund in the Period 2004-2006)

\begin{tabular}{|c|c|c|c|}
\hline \multirow[b]{2}{*}{ Projektum } & \multicolumn{3}{|c|}{ Tervezett költségvetés (millió euró) } \\
\hline & $\begin{array}{l}\text { Kohéziós } \\
\text { Alap }\end{array}$ & $\begin{array}{l}\text { Allami } \\
\text { hozzájáru- } \\
\text { lás/hitel }\end{array}$ & $\begin{array}{l}\text { Össze- } \\
\text { sen }\end{array}$ \\
\hline $\begin{array}{l}\text { Autópálya útszakasz D1 Menguszfalva - } \\
\text { Szepesjánosfalva }\end{array}$ & 161,7091 & 28,5369 & 190,246 \\
\hline $\begin{array}{l}\text { Autópálya útszakasz Lejtős - Kisfarkasd, } \\
\text { I. rész Lejtős - Vágbeszterce }\end{array}$ & 17,7905 & 3,1395 & 20,93 \\
\hline $\begin{array}{l}\text { Vasúti vonal modernizációja Nagyszom- } \\
\text { bat - Vágújhely, II. rész Pöstyén - } \\
\text { Vágújhely }\end{array}$ & 53,38 & 9,42 & 62,8 \\
\hline $\begin{array}{l}\text { Vasúti pálya modernizációja Zsolna - } \\
\text { Csaca, I. rész: Zsolna - Karásznó }\end{array}$ & 60,775 & 10,725 & 71,5 \\
\hline
\end{tabular}

Forrás: Szlovák Köztársaság Közlekedési Minisztériuma (2008).

A Szlovák Köztársaság Közlekedési Minisztériuma a Kohéziós Alapból 2004-2006 között az országot közvetlenül érintő négy multimodális közlekedési folyosóból kettő folyosót (V/A és VI) érintỏ beruházásokat valósított meg - melyek mindegyike elkerüli a magyar kisebbségi tér leghátrányosabb régióit, hasonlóan a következö programozási időszakban (2007-2013) tervezett projektumokhoz. A Kohéziós Alapból Szlovákia 2004-2006 között több, mint 500 millió euróhoz jutott, mely forrásnak közel felét fordították közlekedési célokra (3. táblázat), a fennmaradó részt pedig a vízgazdálkodási vállalatok által kidolgozott tervezetek kapták meg.

2000-2006 között négy közösségi kezdeményezés volt érvényben az EU-ban:

- INTERREG Program - a határon átnyúló, transznacionális és interregionális együttmúködést támogató program, melynek célja a közösség területének harmonikus, kiegyensúlyozott és tartós fejlődése.

- URBAN Program - a válságban lévő városok és a városi agglomerációk gazdasági és szociális regenerációját elsősegítő program, mely hangsúlyozza a tartós városi fejlődés elömozdítását. 
Lelkes Gábor: A szlovákiai regionális fejlesztéspolitika s annak középtávú dél-szlovákiai határ menti vetülete az uniós támogatáspolitika tükrében. - Tér és Társadalom 22. évf. 2008/3. 151-184. p.

TÉT XXII. évf. 2008 - 3 A szlovákiai regionális fejlesztéspolitika...171

- LEADER Program - vidékfejlesztés támogatását célul tüző program.

- EQUAL Program - a munkaerőpiacon előforduló diszkrimináció és az egyenlötlenség minden fajtája ellen vívott harcot támogató program.

A 2004-2006 között a négy érvényben levö közösségi kezdeményezésböl kettö lett meghirdetve Szlovákiában: az INTERREG $\mathrm{III}^{22}$ és az EQUAL. Az INTERREG III program kapcsán megemlítendö, hogy számos civil szervezet bírálta, hogy az INTERREG IIIA kezdeményezésen belül a Szlovákiát érintő fejlesztési programok INTERREG IIIA Program Szlovákia/Ausztria; INTERREG IIIA Program Szlovákia/Lengyelország; INTERREG IIIA Program Szlovákia/Csehország; INTERREG III A/TACIS Program Szlovákia/Magyarország/Ukrajna - források tekintetében nem vették figyelembe az egyes határszakaszok hosszát: a szlovák-magyar és a szlovákukrán határhossz többszöröse a szlovák-osztrák határszakasznak, ennek ellenére a források többszörösét adták az utóbbi határszakaszra (4. táblázat).

\section{TÁBLÁZAT}

Az ERDF által a megjelölt programok céljainak megvalósitására elkülönített pénzeszközök az INTERREG III A programokon belül 2004-2006

(Divisoin of ERDF's Budget Allocated into INTERREG IIIA Programs in the Period 2004-2006)

\begin{tabular}{lc}
\hline \multicolumn{1}{c}{ Program } & Pénzeszközök nagysága \\
\hline INTERREG IIIA Program Szlovákia/Ausztria & 9,50 millió EUR + 25\% társ- \\
finanszírozás \\
INTERREG IIIA Program Szlová- & 9,50 millió EUR + 25\% társ- \\
kia/Lengyelország & finanszírozás \\
INTERREG IIIA Program Szlovákia/Csehország & $\begin{array}{c}4,67 \text { millió EUR + 25\% társ- } \\
\text { finanszírozás }\end{array}$ \\
INTERREG IIIA/TACIS Program Szlovákia- & 9,50 millió EUR + 25\% társ- \\
Magyarország-Ukrajna & finanszírozás \\
\hline
\end{tabular}

Forrás: Szlovák Köztársaság Épitésügyi és Regionális Fejlesztési Minisztériuma (2007).

Az EU 2007-2013 programozási időszakára vonatkozóan az ország stratégiai fejlesztési terve Szlovák Köztársaság Nemzeti Stratégiai Referencia Kerete 2007-2013 címmel került kidolgozásra az EU stratégiai iránymutatásaival összhangban, s még a Dzurinda-kormány 2006 májusában jóváhagyta, késöbb azonban a júniusi kormányváltást követően az új kormány átdolgozta a fejlesztési tervet, amelyet aztán az Európa Bizottság csak 2007 augusztusában fogadott el (5.-8. táblázat). 
Lelkes Gábor: A szlovákiai regionális fejlesztéspolitika s annak középtávú dél-szlovákiai határ menti vetülete az uniós támogatáspolitika tükrében. - Tér és Társadalom 22. évf. 2008/3. 151-184. p.

\section{TÁBLÁZAT}

Szlovák Köztársaság Nemzeti Stratégiai Referencia Kerete 2007-2013 által meghatározott prioritások rendszere a célterületre (Strategic and Specific Priorities of the National Strategic Reference Framework for the Period 2007-2013)

\begin{tabular}{|c|c|c|}
\hline $\begin{array}{l}\text { Stratégiai } \\
\text { prioritás }\end{array}$ & Specifikus prioritás & Alap \\
\hline \multirow{4}{*}{$\begin{array}{l}\text { 1. Infrastruk- } \\
\text { túra és regio- } \\
\text { nális megkö- } \\
\text { zelíthetőség }\end{array}$} & 1.1 Regionális infrastruktúra & ERDF \\
\hline & 1.2 A környezeti infrastruktúra és környezetvédelem & $\begin{array}{l}\text { ERDF } \\
+\mathrm{KF}\end{array}$ \\
\hline & 1.3 Közlekedési infrastruktúra és tömegközlekedés & $\begin{array}{l}\text { ERDF } \\
+\mathrm{KF}\end{array}$ \\
\hline & 1.4 Egészségügyi infrastruktúra modernizációja & ERDF \\
\hline \multirow{4}{*}{$\begin{array}{l}\text { 2. Tudásalapú } \\
\text { gazdaság }\end{array}$} & 2.1 Társadalom informatizálása & ERDF \\
\hline & 2.2 Kutatás és fejlesztés & ERDF \\
\hline & 2.3 Felsőoktatási intézmények infrastruktúrája & ERDF \\
\hline & $\begin{array}{l}2.4 \text { Vállalatok és szolgáltatások versenyképességének } \\
\text { támogatása innovációk által }\end{array}$ & ERDF \\
\hline \multirow{2}{*}{$\begin{array}{l}\text { 3. Emberi } \\
\text { eröforrás }\end{array}$} & 3.1 Modern oktatás a tudásalapú társadalomért & ESF \\
\hline & $\begin{array}{l}\text { 3.2 Foglalkoztatottság és társadalmi befogadás növekedé- } \\
\text { sének a támogatása, kapacitás építés }\end{array}$ & ESF \\
\hline \multirow{2}{*}{$\begin{array}{l}\text { 4. Technikai } \\
\text { segítség- } \\
\text { nyújtás } \\
\text { (horizontális) }\end{array}$} & $\begin{array}{l}\text { 4.1 Elökészítés, irányítás, monitoring, értékelés, informálás, } \\
\text { adminisztrációs kapacitások erősítése ezeken területeken }\end{array}$ & ERDF \\
\hline & $\begin{array}{l}4.2 \text { Pénzügyi irányítás, ellenőrzés és adminisztrációs kapa- } \\
\text { citások erősítése ezeken területeken }\end{array}$ & ERDF \\
\hline
\end{tabular}

Megjegyzés: A konvergencia program célterülete az ország valamennyi NUTS2 szintjét jelenti, leszámítva Pozsony NUTS2 régiót.

Forrás: Szlovák Köztársaság Nemzeti Stratégiai Referencia Kerete 2007-2013 (2007). 
Lelkes Gábor: A szlovákiai regionális fejlesztéspolitika s annak középtávú dél-szlovákiai határ menti vetülete az uniós támogatáspolitika tükrében. - Tér és Társadalom 22. évf. 2008/3. 151-184. p.

TÉT XXII. évf. 2008 『 3 A szlovákiai regionális fejlesztéspolitika...173

\section{TÁBLÁZAT}

Szlovák Köztársaság Nemzeti Stratégiai Referencia Kerete 2007-2013 által meghatározott prioritások rendszere a „Regionális versenyképesség és foglalkoztatottság" célterületre

(Priorities of the National Strategic Reference Framework for the Regional Competitiveness and Employment Programme)

\begin{tabular}{|c|c|c|}
\hline $\begin{array}{l}\text { Stratégiai } \\
\text { prioritás }\end{array}$ & Specifikus prioritás & Alap \\
\hline \multirow{2}{*}{\multicolumn{2}{|c|}{$\begin{array}{l}\text { 1. Infrastruktúra és regionális elérhetőség } \\
\text { 2. Tudásalapú gazdaság }\end{array}$}} & ERDF \\
\hline & & ERDF \\
\hline \multirow{2}{*}{$\begin{array}{l}\text { 3. Emberi } \\
\text { erőforrás }\end{array}$} & 3.1 Modern oktatás a tudásalapú társadalomért & ESF \\
\hline & $\begin{array}{l}\text { 3.2 Foglalkoztatottság és társadalmi befogadás tá- } \\
\text { mogatása, kapacitás építés }\end{array}$ & ESF \\
\hline
\end{tabular}

Megjegyzés: A „Regionális versenyképesség és foglalkoztatottság” célterület a Pozsony NUTS2 régiót jelenti.

Forrás: Szlovák Köztársaság Nemzeti Stratégiai Referencia Kerete 2007-2013 (2007).

\section{TÁBLÁZAT}

A pénzügyi forrásosztás az EU kohéziós politikájának céljai szerint a 2007-2013 programozási idöszakban

(Financial Allociation for Slovakia for Programming Period 2007-2013 According to EU Cohesion Policy Objectives)

\begin{tabular}{|c|c|c|c|}
\hline \multirow{2}{*}{$\begin{array}{l}\text { EU kohéziós politi- } \\
\text { kájának céljai }\end{array}$} & \multirow{2}{*}{$\begin{array}{c}E U \\
\text { alapjai }\end{array}$} & \multicolumn{2}{|c|}{$\begin{array}{l}\text { Pénzüugyi forrásosztás az EU kohéziós politiká- } \\
\text { jának céljai szerint Szlovákia esetében (EUR) }\end{array}$} \\
\hline & & 2004 árszint & aktuális árszint \\
\hline \multirow{3}{*}{ Konvergencia } & $\begin{array}{c}\mathrm{SA}+ \\
\mathrm{KA}\end{array}$ & 9638999602 & 10911601421 \\
\hline & $\mathrm{SA}$ & 6214921468 & 7012862858 \\
\hline & $\mathrm{KA}$ & 3424078134 & 3898738563 \\
\hline $\begin{array}{l}\text { Regionális ver- } \\
\text { senyképesség és } \\
\text { foglalkoztatottság }\end{array}$ & SA & $\begin{array}{c}398057758 \\
(108782757+\text { a } \\
\text { Konvergencia célból } \\
\text { átutalás a kutatásra és } \\
\text { fejlesztésre } \\
289275001)\end{array}$ & $\begin{array}{c}449018529 \\
(122603156+\text { a } \\
\text { Konvergencia célból } \\
\text { átutalás a kutatásra és } \\
\text { fejlesztésre } \\
326415373)\end{array}$ \\
\hline $\begin{array}{l}\text { Európai Területi } \\
\text { Együtttmüködés }\end{array}$ & SA & 201606786 & 227284545 \\
\hline Összesen & $\begin{array}{c}S A+ \\
K A\end{array}$ & 10238664146 & 11587904495 \\
\hline
\end{tabular}

Megjegyzés: SA - Strukturális Alapok, KA - Kohéziós alap.

Forrás: Szlovák Köztársaság Nemzeti Stratégiai Referencia Kerete 2007-2013 (2007). 
Lelkes Gábor: A szlovákiai regionális fejlesztéspolitika s annak középtávú dél-szlovákiai határ menti vetülete az uniós támogatáspolitika tükrében. - Tér és Társadalom 22. évf. 2008/3. 151-184. p.

\section{TÁBLÁZAT}

Szlovák Köztársaság Nemzeti Stratégiai Referencia Kerete 2007-2013 által megfogalmazott stratégiai célok mérhető mutatói és azok értéke 2013-ban (Measurable Indicators of Strategic Objectives Defined in the National Strategic Reference Framework for the Period 2007-2013)

\begin{tabular}{|c|c|c|}
\hline $\begin{array}{l}\text { Szlovák Köztársaság Nemzeti } \\
\text { Stratégiai Referencia Kerete } \\
2007-2013 \text { által megfogalmazott } \\
\text { stratégiai célok mérhetó mutatói }\end{array}$ & $\begin{array}{l}\text { A mutató értéke } \\
\text { 2005-ben }\end{array}$ & $\begin{array}{l}\text { A mutató értéke } \\
\text { 2013-ban }\end{array}$ \\
\hline A gazdaság energetikai szükséglete & $\begin{array}{l}854,3 \mathrm{kgOE} / 1000 \\
\text { EUR }\end{array}$ & $\begin{array}{l}663,4 \mathrm{kgOE} / 1000 \\
\text { EUR }\end{array}$ \\
\hline Együttes innovációs index & 22. hely az EU25-ben & 22. hely az EU25-ben \\
\hline $\begin{array}{l}\text { Egy före jutó GDP vásárlóerỏ } \\
\text { paritáson számolva az EU15 vi- } \\
\text { szonylatában }\end{array}$ & $\begin{array}{l}\text { Az EU15 szintjé- } \\
\text { nek } 53,7 \% \text {-a }\end{array}$ & $\begin{array}{l}\text { Az EU15 szintjének } \\
\text { több mint } 60 \% \text {-a }\end{array}$ \\
\hline $\begin{array}{l}\text { Munkatermelékenység az EU15 } \\
\text { viszonylatában }\end{array}$ & $\begin{array}{l}\text { Az EU15 szintjé- } \\
\text { nek } 60,9 \% \text {-a }\end{array}$ & $\begin{array}{l}\text { Az EU15 szintjének } \\
\text { több mint } 70 \% \text {-a }\end{array}$ \\
\hline $\begin{array}{l}\text { Foglalkoztatottság mértéke (15- } \\
\text { 64) az EU15 viszonylatában }\end{array}$ & $\begin{array}{l}\text { Az EU15 szintjé- } \\
\text { nek } 57,7 \% \text {-a }\end{array}$ & $\begin{array}{l}\text { Az EU15 szintjének } \\
63,4 \%-a\end{array}$ \\
\hline
\end{tabular}

Megjegyzés: OE - oil equivalent.

Forrás: Szlovák Köztársaság Nemzeti Stratégiai Referencia Kerete 2007-2013 (2007).

A stratégiai tervdokumentum tartalmazza az ország gazdasági és társadalmi felemelkedése végett prioritásként kezelendỏ területeket és aktivitásokat a felvázolt idöszakra, melyek számára a forrásokat a Strukturális Alapok és a Kohéziós Alap biztosítja majd, s amely alapok a 2007-2013 közötti programozási időszakban három új célkitúzést támogatnak: a konvergenciát, a regionális versenyképességet és foglalkoztatást, valamint az európai területi együttmüködést (6. táblázat). A tervdokumentum a 2007-2013 programozási időszakra stratégiai célként a régiók, a szlovák gazdaság és a foglalkoztatottság versenyképességének és teljesítóképességének jelentös emelését célozta meg a fenntartható fejlödés feltételeinek betartása mellett. Ezen cél elérése végett elsőszámú célterületként a régiók növekedési centrumainak a támogatását jelöli meg, abból a feltételezésböl kiindulva, hogy a gazdaságitársadalmi felemelkedés a régiók centrumából majd fokozatosan kiáramlik a régiók marginális tereibe ${ }^{23}$. A stratégiai cél elérése végett a dokumentum kiemeli a régiók szerepkörének megnövelését, és a partnerségek létrehozásának a szükségét a források hatékony felhasználása végett. 
Lelkes Gábor: A szlovákiai regionális fejlesztéspolitika s annak középtávú dél-szlovákiai határ menti vetülete az uniós támogatáspolitika tükrében. - Tér és Társadalom 22. évf. 2008/3. 151-184. p.

TÉT XXII. évf. 2008 a 3 A szlovákiai regionális fejlesztéspolitika...175

\section{TÁBLÁZAT}

A 2007-2013 uniós programozási idöszak operativ programjai (Operational Programmes of Programming Period 2007-2013)

\begin{tabular}{|c|c|c|}
\hline & Operativ Program & Irányitó Hatóság \\
\hline 1. & Közlekedés & $\begin{array}{l}\text { SzK Közlekedés, Posta és Telekommu- } \\
\text { nikációs Minisztériuma }\end{array}$ \\
\hline 2. & Környezetvédelem & SzK Környezetvédelmi Minisztériuma \\
\hline 3. & Regionális fejlesztés & $\begin{array}{l}\text { SzK Építésügyi és Regionális Fejlesztési } \\
\text { Minisztériuma }\end{array}$ \\
\hline 4. & Társadalom informatizálása & SzK Kormányhivatala \\
\hline 5. & Egészségügy & SzK Egészségügyi Minisztériuma \\
\hline 6. & $\begin{array}{l}\text { Foglalkoztatás és társadalmi } \\
\text { befogadás }\end{array}$ & $\begin{array}{l}\text { SzK Munka-, Szociális- és Családügyi } \\
\text { Minisztériuma }\end{array}$ \\
\hline 7. & Oktatás & SzK Oktatásügyi Minisztériuma \\
\hline 8. & Kutatás és fejlesztés & SzK Oktatásügyi Minisztériuma \\
\hline 9 & $\begin{array}{l}\text { Versenyképesség és gazdasági } \\
\text { növekedés }\end{array}$ & SzK Gazdasági Minisztériuma \\
\hline 10 & Pozsonyi kerület & $\begin{array}{l}\text { SzK Építésügyi és Regionális Fejlesztési } \\
\text { Minisztériuma }\end{array}$ \\
\hline 11. & Technikai segítségnyújtás & $\begin{array}{l}\text { SzK Építésügyi és Regionális Fejlesztési } \\
\text { Minisztériuma }\end{array}$ \\
\hline
\end{tabular}

Forrás: Szlovák Köztársaság Nemzeti Stratégiai Referencia Kerete 2007-2013 (2007).

A tervdokumentum alapján 11 operatív program került kidolgozásra, melyböl egy operatív program a technikai segítségnyújtásra irányul (9. táblázat). Az operatív programok tartalmazzák az állam legfontosabb prioritásait, valamint a programozás végrehajtásának módját. Az EU egyetlen kikötéssel él a támogatás-felhasználás programozása tekintetében: a „konvergencia” célkitúzés kedvezményezettjei közé tartozó országok és régiók a támogatások $60 \%$-át, a „versenyképesség és foglalkoztatás" célkitüzés keretei közt támogatható országok és régiók pedig a támogatások 75\%-át kötelesek a lisszaboni stratégiában megfogalmazott uniós prioritások, azaz a növekedés és a foglalkoztatás fellendítésére fordítani.

Az uniós források szétosztásával kapcsolatosan a területi koncentráció elvét követve a SZK Nemzeti Stratégiai Referencia Kerete 2007-2013 az ország településeit három kategóriába sorolta be (10.-12. táblázat):

- innovációs növekedési pólusok ( 82 város kapott besorolást ezen kategóriába),

- kohéziós növekedési pólusok (891 város és község kapott besorolást ezen kategóriába),

- községek, amelyek nem növekedési pólusok (1918 község kapott besorolást ezen kategóriába). 
Lelkes Gábor: A szlovákiai regionális fejlesztéspolitika s annak középtávú dél-szlovákiai határ menti vetülete az uniós támogatáspolitika tükrében. - Tér és Társadalom 22. évf. 2008/3. 151-184. p.

176 Lelkes Gábor

TÉT XXII. évf. 2008 - 3

\section{TÁBLÁZAT}

Az ország településeinek osztályozása a területi koncentráció elve alapján -I.

(Division of Municipalities Based on the Principle of Territorial Concentration - I.)

\begin{tabular}{|c|c|c|c|c|}
\hline & & \multicolumn{2}{|c|}{ Népesség száma } & \multirow{2}{*}{$\begin{array}{l}\text { Települé- } \\
\text { sek szá- } \\
\quad \text { ma }\end{array}$} \\
\hline & $\overrightarrow{E v}$ & 2001 & 2004 & \\
\hline 1 & Innovációs növekedési pólusok & 2673296 & 2642677 & 82 \\
\hline \multirow[t]{2}{*}{2} & Kohéziós növekedési pólusok & 1794183 & 1819978 & 891 \\
\hline & $\begin{array}{l}\text { Innovációs és kohéziós növekedési pólu- } \\
\text { sok összesen }(1+2)\end{array}$ & 4467479 & 4462655 & 973 \\
\hline 3 & $\begin{array}{l}\text { Községek, amelyek nem növekedési pólu- } \\
\text { sok, ugyanakkor az innovációs növekedési } \\
\text { pólusok vonzáskörzetében fekszenek }\end{array}$ & 257153 & 266413 & 415 \\
\hline \multirow[t]{2}{*}{4} & $\begin{array}{l}\text { Községek, amelyek nem növekedési pólu- } \\
\text { sok, ugyanakkor nem fekeszenek innová- } \\
\text { ciós növekedési pólusok vonzáskörzetében }\end{array}$ & 654823 & 655754 & 1503 \\
\hline & Összesen & 5379455 & 5384822 & 2891 \\
\hline
\end{tabular}

Forrás: Szlovák Köztársaság Épitésügyi és Regionális Fejlesztési Minisztériuma (2007).

\section{TÁBLÁZAT}

A területi koncentráció elve alapján végrehajtott osztályozása az ország településeinek növekedési pólusokra és nem növekedési pólusokra - II. (\%)

(Division of Municipalities Based on the Principle of Territorial Concentration into

Developing Poles and Non-developing Pole - II.)

\begin{tabular}{|c|c|c|c|c|}
\hline & \multirow[b]{3}{*}{ Év } & \multirow{2}{*}{\multicolumn{2}{|c|}{$\begin{array}{l}\text { Népesség } \\
\text { részaránya }\end{array}$}} & \multirow{3}{*}{$\begin{array}{l}\text { Települé- } \\
\text { sek rész- } \\
\text { aránya }\end{array}$} \\
\hline & & & & \\
\hline & & 2001 & 2004 & \\
\hline 1 & Innovációs növekedési pólusok & 49,7 & 49,1 & 2,8 \\
\hline \multirow[t]{2}{*}{2} & Kohéziós növekedési pólusok & 33,4 & 33,8 & 30,8 \\
\hline & $\begin{array}{l}\text { Innovációs és kohéziós növekedési pólu- } \\
\text { sok összesen }(1+2)\end{array}$ & 83,0 & 82,9 & 33,7 \\
\hline 3 & $\begin{array}{l}\text { Községek, amelyek nem növekedési pó- } \\
\text { lusok, ugyanakkor az innovációs növeke- } \\
\text { dési pólusok vonzáskörzetében fekszenek } \\
\text { Községek, amelyek nem növekedési pó- } \\
\text { lusok, ugyanakkor nem fekeszenek inno- } \\
\text { vációs növekedési pólusok vonzáskörze- }\end{array}$ & 4,8 & 4,9 & 14,4 \\
\hline 4 & tében & 12,2 & 12,2 & 52,0 \\
\hline & Összesen & 100,0 & 100,0 & 100,0 \\
\hline
\end{tabular}

Forrás: Szlovák Köztársaság Építésügyi és Regionális Fejlesztési Minisztériuma (2007). 
Lelkes Gábor: A szlovákiai regionális fejlesztéspolitika s annak középtávú dél-szlovákiai határ menti vetülete az uniós támogatáspolitika tükrében. - Tér és Társadalom 22. évf. 2008/3. 151-184. p.

TÉT XXII. évf. 2008 = 3 A szlovákiai regionális fejlesztéspolitika...177

Az előző beosztás alapján a legkedvezőbb fejlesztési körülményekkel az innovációs növekedési pólusok rendelkeznek majd a 2007-2013 programozási időszakban. A második legkedvezőbb fejlesztéstámogatási környezetet a kohéziós növekedési pólusok mondhatják a magukénak, míg a legkevesebb támogatást azon községek kapják majd, amelyek nem növekedési pólusok.

\section{TÁBLÁZAT}

A területi koncentráció elve a Szlovák Köztársaság Nemzeti Stratégiai Referencia

Kerete 2007-2013 specifikus prioritásainak végrehajtásával kapcsolatosan

(The Principle of Territorial Concentration in Relation to Specific Priorities of the

National Strategic Reference Framework for the Period 2007-2013)

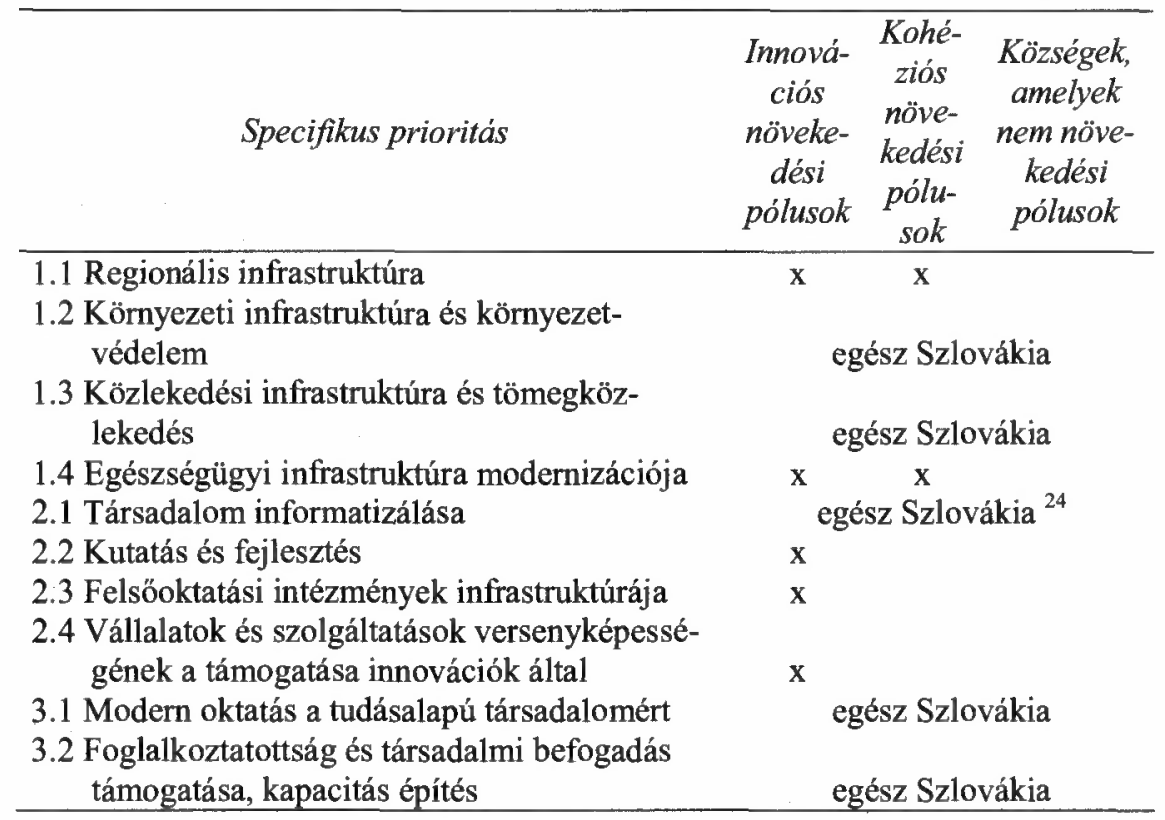

Megjegyzés: $\mathrm{x}$ - a megvalósítandó projektek helyszine .

Forrás: Szlovák Köztársaság Nemzeti Stratégiai Referencia Kerete 2007-2013 (2007).

A Nemzeti Stratégiai Referencia Keret 2007-2013 dokumentumban a stratégiai prioritások mellett megfogalmazásra kerültek a horizontális prioritások is, amelyek ugyanolyan fontosak, mint a stratégiai prioritások, de átfogó jellegüknél fogva nem valósithatók meg külön intézkedések révén, és megvalósításukra nem különíthetó el keret (13. táblázat). A horizontális prioritásokat egyrészt a programozási folyamat egészében, másrészt valamennyi támogatott programban érvényesíteni kell. A Nemzeti Stratégiai Referencia Keret 2007-2013 az alábbi négy horizontális prioritásokat tartalmazza:

- marginalizált roma közösségek,

- esélyegyenlőség,

- tartósan fenntartható fejlödés,

- információs társadalom. 
Lelkes Gábor: A szlovákiai regionális fejlesztéspolitika s annak középtávú dél-szlovákiai határ menti vetülete az uniós támogatáspolitika tükrében. - Tér és Társadalom 22. évf. 2008/3. 151-184. p.

178 Lelkes Gábor

TÉT XXII. évf. 2008

\section{TÁBLÁZAT}

Szlovák Köztársaság Nemzeti Stratégiai Referencia Keretének horizontális prioritásai, azok céljai és alkalmazásának módjai

(Horizontal Priorities of the National Strategic Reference Framework for the Period 2007-2013)

\begin{tabular}{|c|c|c|}
\hline $\begin{array}{l}\text { Horizontális } \\
\text { prioritások }\end{array}$ & $\begin{array}{c}\text { Horizontális } \\
\text { prioritások célja }\end{array}$ & $\begin{array}{c}\text { Horizontális } \\
\text { prioritások érvényesülése }\end{array}$ \\
\hline $\begin{array}{l}\text { marginalizált } \\
\text { roma közősségek }\end{array}$ & $\begin{array}{l}\text { a marginalizált roma közössé- } \\
\text { gek foglalkoztatottsági és } \\
\text { iskolázottsági szintjének nö- } \\
\text { velése, valamint életkörülmé- } \\
\text { nyeik javítása }\end{array}$ & $\begin{array}{l}\text { átfogó megközelítés (több operatív } \\
\text { program segítségével) }\end{array}$ \\
\hline esélyegyenlőség & $\begin{array}{l}\text { az esélyegyenlöség biztosítása } \\
\text { a diszkrimináció minden for- } \\
\text { májával szemben }\end{array}$ & az összes projektnél alkalmazott elv \\
\hline $\begin{array}{l}\text { tartósan fenntart- } \\
\text { ható fejlődés }\end{array}$ & $\begin{array}{l}\text { a gazdasági növekedés kör- } \\
\text { nyezeti, gazdasági és társa- } \\
\text { dalmi fenntarthatóságának } \\
\text { biztosítása }\end{array}$ & $\begin{array}{l}\text { elv a Szlovák Köztársaság Nemzeti } \\
\text { Stratégiai Referencia Keretének } \\
\text { szintjén }\end{array}$ \\
\hline $\begin{array}{l}\text { információs társa- } \\
\text { dalom }\end{array}$ & $\begin{array}{l}\text { a befogadó információs társa- } \\
\text { dalom fejlesztése }\end{array}$ & $\begin{array}{l}\text { integrált megközelítés (a közigazga- } \\
\text { tás információs rendszereinek fej- } \\
\text { lesztése és e-szolgáltatások beveze- } \\
\text { tése az operatív programokban) }\end{array}$ \\
\hline
\end{tabular}

Forrás: Szlovák Köztársaság Nemzeti Stratégiai Referencia Kerete 2007-2013 (2007).

A Nemzeti Stratégiai Referencia Keret 2007-2013 dokumentum mellett a regionális fejlesztés kereteit illetően további meghatározó dokumentum a Szlovák Köztársaság Nemzeti Stratégiai Vidékfejlesztési Terve 2007-2013, amelyhez az EAFRD (European Agricultural Fund for Rural Development - Európai Mezőgazdasági Vidékfejlesztési Alap) biztosítja a forrást. Ezen tervdokumentum elsósorban a vidéki térségek folyamatosan fenntartható fejlődésére irányul, ezért a dokumentum prioritásai, a vidékfejlesztési támogatási programok a mezőgazdasági termelés és erdỏgazdálkodás versenyképességének javítására, a talajjal való ésszerủ gazdálkodás támogatására, a környezet javítására, a vidéki életfeltételek javítására és a gazdasági tevékenységek diverzifikálására összpontosítanak. Ezen programdokumentum különösen fontos szerepet tölthet be a szlovákiai magyar kisebbség által lakott tér fejlesztésében, ugyanis a dokumentum prioritásai elsósorban a periférikus vidéki régiók támogatását célozzák, mely kategóriába tartozik a szlovákiai magyar kisebbségi tér döntő hányada. A vidékfejlesztési stratégia ezen irányultságának kiemelése azért fontos, mivel a Nemzeti Stratégiai Referencia Keret 2007-2013 dokumentum stratégiája a településfejlesztés terén csupán az innovációs és kohéziós növekedési centrumok, valamint a szegregált telepủlések támogatása (abban a reményben, hogy a centrumok fejlődése idővel kiváltja a periférikus települések fejlödését is). 
Lelkes Gábor: A szlovákiai regionális fejlesztéspolitika s annak középtávú dél-szlovákiai határ menti vetülete az uniós támogatáspolitika tükrében. - Tér és Társadalom 22. évf. 2008/3. 151-184. p.

TÉT XXII. évf. 2008 — 3 A szlovákiai regionális fejlesztéspolitika...179

A Szlovák Köztársaság Nemzeti Stratégiai Vidékfejlesztési Terve 2007-2013 dokumentumban négy fejlesztési tengelyt határoztak meg:

- 1. fejlesztési tengely: Versenyképesség javitása ${ }^{25}$

- 2. fejlesztési tengely: Életkörnyezet és táj javitása ${ }^{26}$

- 3. fejlesztési tengely: Vidéki életfeltételek javítása ${ }^{27}$

- 4. fejlesztési tengely: LEADER stratégia alkalmazása ${ }^{28}$.

A 2007-2013 programozási időszakban Szlovákia vidékfejlesztési programjára mintegy 1,9 milliárd euró jut, melynek megoszlása az alábbi arányban várható: versenyképesség javítása ( $20 \%$ ), életkörnyezet és táj javítása $(63,5 \%)$, vidéki életfeltételek javitása $(12,5 \%)$, LEADER stratégia alkalmazása $(2,5 \%)$, technikai segítségnyújtás $(2 \%)$.

A 2007-2013 programozási időszakban a Nemzeti Stratégiai Vidékfejlesztési Terv 2007-2013 dokumentum mellett a vidéki terek fejlesztése szempontjából meghatározó programdokumentumnak számít még a Halászati Operativ Program, amelyhez a forrást az EFF (European Fisheries Fund - Európai Halászati Alap) biztosítja. Ezen tervdokumentum stratégiai céljai az ország halgazdaságának és akva-kultúrájának modernizációjára és restrukturalizációjára, a halgazdaságok és akvakultúrák termékeinek feldolgozásával foglalkozó vállalatok versenyképességének növelésére és a halászati termékek piacának fejlesztésére irányulnak.

A 2007-2013 közötti időszakban az Európai Bizottság döntése értelmében fontos újításként a kohéziós politika fó programjaiba kerültek az eddig közösségi kezdeményezésként müködő határon átnyúló együttmüködési programok (INTERREG). 2007-től a határon átnyúló együttmüködési programok kiemelt célkitüzésként szerepelnek - mint 3. célkitüzés az Európai Területi Együttmüködés (ETC) ${ }^{29}$ megnevezés alatt. A célkitüzés alatti támogatásra jogosult területek:

- határon átnyúló együttmüködés - a Közösség NUTS3 szintủ szárazföldi vagy tengeri határok mentén fekvő régiói, illetve az ENPI program esetén az EU-val szomszédos (nem tagállam) országok NUTS3 szintü régiói is,

- transznacionális együttmüködés - a Bizottság a transznacionális térségek listáját programok szerint határozza meg a részt vevő országokkal egyeztetve

- interregionális együttmüködés - a Közösség egész területe. Szlovákia esetében az ország valamennyi NUTS3 régiójának van legalább egy nemzetközi határa valamely szomszédos országgal, így az összes NUTS3 régió részt vehet az EU által támogatott határmenti együttmüködésekben.

Az ETC programok közt kiemelkedő fontosságúak a határon átnyúló együttmüködési programok, melyek fó célja a határok elválasztó jellegének csökkentése, a határon átnyúló infrastruktúrák és együttmüködések fejlesztése, ill. a határ menti közösségek kapcsolatainak erősítése. Az egyes programok regionális fejlesztési jellegüek, de a regionális fejlesztésnek kizárólag azon területeit ölelik fel, ahol a nemzeti határokon átlépö együttmüködések a fỏáramú fejlesztésekhez képest hozzáadott értéket hordoznak, illetve olyan közös problémákat céloznak megoldani, melyek gátolják a részt vevő országok kapcsolódó területei tekintetében az egymásra ható fejlesztések 
Lelkes Gábor: A szlovákiai regionális fejlesztéspolitika s annak középtávú dél-szlovákiai határ menti vetülete az uniós támogatáspolitika tükrében. - Tér és Társadalom 22. évf. 2008/3. 151-184. p.

összehangolását, kölcsönös kihasználását. Ez lehetőséget nyưjt a határ menti területek olyan fejlesztésére, mely enyhíti a helyi népesség helyenként fennálló gazdasági és társadalmi elszigeteltségét. A 2007-2013 programozási időszakban Szlovákia és a szomszédos államok közt öt határon átnyúló együttmủködési program került meghirdetésre, amelyek közt a dél-szlovákiai régiót a NUTS3 beosztás alapján négy érinti: a szlovák-cseh határon átnyúló együttmúködési program, a szlovák-osztrák határon átnyúló együttmủködési program, a szlovák-magyar határon átnyúló együttmúködési program, valamint a szlovák-ukrán, ukrán-magyar és román-ukrán határon átnyúló együttmúködést segítő Magyarország-Szlovákia-Románia-Ukrajna Európai Szomszédsági és Partnerségi Eszköz Határon Átnyúló Együttmủködési Program.

\section{Összefoglalás}

Az elmúlt tíz évben Szlovákiában a regionális fejlesztéspolitikát illetően hatalmas változások mentek végbe, melynek köszönhetően többek között Dél-Szlovákia társadalmi és gazdasági környezete is jelentősen javult. A fejlesztéspolitikai reformok ereménnyeképpen napjainkra a fejlesztéspolitikai döntéshozatal közel került a lakosokhoz, kis túlzással a szubszidiaritás eszméjének gyôzelme valósult meg, a települések és régiók lényegesen befolyásolhatják a környezetük fejlődési irányát, a regionális térszerkezet formálódását.

A fejlesztési döntéshozatal decentralizációjával a dél-szlovákiai fejlesztési politikában megjelent a szlovák-magyar határ fokozatos légiesedése, a dél-szlovákiai lokális és regionális önkormányzatok jelentős része a fejlesztési döntéshozatalukban figyelmet szentel a szomszédos magyarországi települések és régiók sajátosságainak, s számos esetben közös fejlesztési lépések is megfogalmazódnak. Az uniós eszmék - és az 1999-2006 között tapasztalt szlovák-magyar nemzeti közeledés ráébresztették a fejlesztéspolitika lokális és regionális szereplöinek nagy részét arra, hogy sikeres fejlesztéspolitikát nem lehet elszigetelten, országos keretek közt megvalósítani, hanem a határokon átnyúló térben kell gondolkodni. Az utóbbi fejlesztéspolitikai megközelítéshez a 2007-2013 időszakban lényeges forrást biztosít a dél-szlovákiai régiók számára több határon átnyúló egyủttmủködési program.

Az elkövetkező tíz évben az ország településeinek és régióinak fejlesztéséhez hatalmas segítséget nyújtanak majd az uniós fejlesztési források, a régiók akár több évtizedes területi hátrányokat dolgozhatnak le a Nemzeti Stratégiai Referencia Keretben és a Nemzeti Stratégiai Vidékfejlesztési Tervben megfogalmazott prioritásoknak köszönhetóen. A magyarlakta települések és régiók társadalmi-gazdasági felemelkedésének fejlesztéspolitikai stratégiai hátterére azonban sok esetben árnyékot vet a szlovák kormányok és önkormányzati régiók nacionalista fejlesztéspolitikai térszemlélete, amelynek lényege a többségében szlovákok által lakott települések és régiók prioritásainak támogatása, az amúgy is gazdaságilag fejlettebb és jobb alapinfrastruktúrával rendelkezó régiók pozitív diszkriminálása az elmaradottabb dél-szlovákiai régiókkal szemben. 
Lelkes Gábor: A szlovákiai regionális fejlesztéspolitika s annak középtávú dél-szlovákiai határ menti vetülete az uniós támogatáspolitika tükrében. - Tér és Társadalom 22. évf. 2008/3. 151-184. p.

\section{Jegyzetek}

${ }^{1}$ A dokumentum az ország regionális tagolásánal (Pozsony kerület; Délnyugat Szlovákia - Nagyszombati kerület, Nyitrai kerület; Északnyugat Szlovákia - Trencséni kerület, Zsolnai kerület; Kelet Szlovákia - Besztercebányai kerület, Eperjesi kerület, Kassai kerület) nem az uniós statisztikai hivatal - az Eurostat - által használt NUTS2 regionális tagoltságot alkalmazta (Pozsony kerület; Nyugat Szlovákia - Nagyszombati kerület, Nyitrai kerület, Trencséni kerület; Közép Szlovákia - Zsolnai kerület, Besztercebányai kerület; Kelet Szlovákia - Eperjesi kerület, Kassai kerület), ami az 1999-2001 idöszakban számos problémát okozott az EU-val folytatott tárgyalások során, s végülis 2002-ben a kormány elegett tett az uniós kérelemnek, $\mathrm{s}$ az uniós NUTS2 szintekhez igazította az ország regionális politikai tagoltságát.

Az eurorégiók meghatározásánál bonyolító tényezö, hogy több szervezet használja az eurorégió megjelölést, holott ténylegesen nem azok. Ennek az az oka, hogy nincs szabályozva, mely szervezetek jogosultak a nevet használni, emiatt baráti társaságok, egyesületek is felveszik, használják a megnevezést. A 12 eurorégió a szlovákiai régiófejlesztési minisztérium által regisztrált eurorégiós együttmúködés.

${ }^{3}$ A kivételt a Kárpátok Eurorégió képezi, mely öt állam határ menti régióit ơleli fel.

${ }^{4}$ A fenti területeken az alábbi jogi formában müködnek a civil szervezetek: polgári társulások (a jogi forma kereteit a 83/1990 T.t. számú törvény határozza meg), alapitványok (a jogi forma kereteit a 34/2002 Tt. számú törvény határozza meg), jótékonysági alapok (a jogi forma kereteit a 147/1997 T.t. számú törvény határozza meg), közhasznú szolgáltatásokat nyújtó szervezetek (a jogi forma kereteit a $35 / 2002$ T.t. számú törvény határozza meg).

${ }^{5}$ A fenti területeken az alábbi jogi formában mükődnek a civil szervezetek: polgári társulások (a jogi forma kereteit a 83/1990 T.t. számú törvény határozza meg), alapítványok (a jogi forma kereteit a 34/2002 Tt. számú törvény határozza meg), jótékonysági alapok (a jogi forma kereteit a 147/1997 T.t. számú törvény határozza meg), közhasznú szolgáltatásokat nyújtó szervezetek (a jogi forma kereteit a 35/2002 T.t. számú tơrvény határozza meg).

${ }^{6}$ Fontos megjegyezni, hogy az uniós csatlakozás után lett általános a projektek utólagos támogatása. Ez nagy vitát váltott ki a civil szervezetek körében, ugyanis a források utólagos szétosztása tơbb esetben lehetetlenné tette a civil szervezet müködését.

${ }^{7}$ Alapvető feladatuk a pályázatok fogadása, elöminösítése, elszámolása és ellenőrzése, amiért a sikeres, tehát elfogadott pályázatok után díjazásban részesülnek az éves egyszeri és egységes juttatáson felül. Miután a központ maga is sikerérdekelt vállalkozásként tevékenykedik, magának is évente pályáznia kell, hogy elláthassa ezt a tevékenységet (a siker mércéje az elfogadott pályázatok száma).

${ }^{8}$ A regionális folyamatok elemzése megkívánja, hogy megfelelö szintủ területi bontásban adatok álljanak a rendelkezésre. E felismerésböl kiindulva az Európai Unió a közigazgatási egységekre alapozva létrehozta a Területi Statisztikai Egységek Nómenklatúráját (NUTS, Nomenclature des Unités Territoriales Statistiques). Az ötfokozatú területi statisztikai rendszerhez illeszkedve Szlovákiában a NUTS1 szint magát az országot jelenti. A NUTS2 szinten, a tervezési-statisztikai régiók szintjén, 4 (Pozsony, Nyugat-Szlovákia, Közép-Szlovákia, Kelet-Szlovákia), míg a NUTS3 szinten, a fejlesztési régiók szintjén, 8 (Pozsonyi kerület, Nyitrai kerület, Nagyszombati kerület, Trencséni kerület, Zsolnai kerület, Besztercebányai kerullet, Kassai kerület, Eperjesi kerület) régió lett lehatárolva. A NUTS4 szintnek, a statisztikai kistérségeknek, a járások, a NUTS5 szintnek pedig maguk a települések felelnek meg

9

A Phare Elö́csatlakozási Programot (Pologne-Hongrie Aid a la Reconstruction Économique) 1989-ben hozta létre az Európai Közősség, eredetileg azzal a céllal, hogy támogatassa Lengyelország és Magyarország gazdasági szerkezetátalakítását. A gazdasági és politikai átmenet elősegitésére 1989-ben létrehozott Phare programot 1996-ra úgy bővítették ki, hogy akkor már a közép-európai régió 13 országában jelen volt.

${ }^{10}$ Az ISPA Elöcsatlakozási Program (Instrument for Structural Policies for Pre-Accession) a környezetvédelmi és a közlekedési infrastruktúra fejlesztését szolgáló nagyberuházásokat támogatta az EU-hoz csatlakozni kívánó államokban. Az Agenda 2000-ben az Európai Bizottság javasolta, hogy a Phare programot az EU tagságra váró országok felkészitésére összpontosítsák, a segítséget az acquis communautaire átvételénél két alapvetỏen fontos, kritikus témára - az intézményépítésre és a beruházások támogatására - koncentrálják. 
Lelkes Gábor: A szlovákiai regionális fejlesztéspolitika s annak középtávú dél-szlovákiai határ menti vetülete az uniós támogatáspolitika tükrében. - Tér és Társadalom 22. évf. 2008/3. 151-184. p.

11 A SAPARD Előcsatlakozási Program (Special Accession Programme for Agriculture and Rural Development) a közép-európai reformországokban elsősorban a magánszektort felölelő önkormányzati, térségi kezdeményezéseket támogatta az EU Közösségi Agrárpolitikájába való bekapcsolódás céljából, így járulva hozzá a fenntartható mezőgazdaság és vidékfejlesztés kialakításához.

${ }^{12}$ Az Európai Unió közösségi regionális politika támogatási prioritásainak megnevezése a 2006-2007 programozási idészakban, amelyeken belül az alábbi kategóriák használatosak:

1. célkitüzés: A fejlődésben leginkább elmaradott régiók támogatására irányuló regionális politikai célkitüzés, amelynek keretében az EU Strukturális Alapjaiból származó kiadások 2/3-át költik el.

2. célkitüzés: A gazdasági és társadalmi szerkezetátalakítás miatt strukturális problémákkal küzdö ipari, vidéki, halászati és városi régiók támogatására irányuló regionális politikai célkitüzés.

3. célkitüzés: Az EU regionális politikájának keretében az oktatási és képzési rendszerek modernizációjához támogatást nyújtó célkitüzés. A támogatás a humán eröforrások fejlesztését célozza.

13 Az Európai Regionális Fejlesztési Alapot az Európai Szociális Alappal együtt 1975-ben a Strukturális Alapok részeként hozták létre annak érdekében, hogy támogassák az EU szegényebb régióinak infrastrukturális fejlszetését. Ahogy az EU tagországainak száma gyarapodott, az ERDF a fơ regionális különbségek mérséklésének legföbb eszközévé vált - segítette az elmaradott térségek fejlödését, gazdasági és szociális átalakulását.

14 Az első Strukturális Alap, amelyet EU-költségvetés részeként, a Római Szerződés alapján létrehoztak. Ez az alap az EU munkahelyek létrehozását és védelmét szolgáló politikájának fó finnaszírozója. Az Európai Szociális Alap végső soron az EU egyes régiói közötti életszínvonalbeli különbségek mérséklését szolgálja.

15 Az agrárpolitika finanszírozására közős pénzügyi alapként 1962-ben lett létrehozva, amelynek Garancia Szekciója az intervenciós politika, Orientációs Szekciója az ágazati struktúrapolitika, szerkezetátalakítás anyagi hátterének biztosítását szolgálta.

16 A 'legifjabb' Strukturális Alap - 1993-ban hozták létre a halászattal foglalkozó térségek gazdaságitársadalmi struktúrájának fejlesztésére, szerkezet-átalakításának támogatására.

17 Irányító hatósága a Földmúvelődésügyi Minisztérium Sturkturális Politika Osztálya.

${ }^{18}$ Irányító hatósága a Munkaügyi-, Szociális- és Családügyi Minisztérium, HE OP Irányító Szerv Osztálya

19 Irányító hatósága a Gazdasági Minisztérium, a Kis- és Középvállalkozások Fejlesztéséért Nemzeti Ügynökség - Ágazati Operatív Program Irányító Osztálya

${ }^{20}$ Irányitó hatósága az Építésügyi és Regionális Fejlesztési Minisztérium AI OP-t Irányító Osztály

21 A Kohéziós Alap a projektumok költségvetésének 85\%-át biztosítja.

22 Az INTERREG III. három területen valósul meg:

- a szomszédos határ menti régiók integrált fejlődésének támogatása (A cél - határon átnyúló együttmüködés);

- az egész Unió keretein belüli területi integráció harmonizálása (B cél - transznacionális együttmúködés);

- a regionális fejlődés és a kohéziós politika nemzetek feletti/interregionális együttmüködéseken keresztüli támogatása ( $\mathrm{C}$ cél - interregionális együttmúködés).

23 A regionális fejlödésnek ezen megközelítését és beépítését a Nemzeti Stratégiai Referencia Kerete 2007-2013 c. tervdokumentumba a szlovákiai civil szféra élesen bírálta, ugyanis az ő megítélésük szerint a centrumok kiemelt támogatása fokozza a centrum-periféria közti gazdasági-társadalmi szakadékot.

24 A kulturális alapintézmények kivételével, amelyek esetében a források az innovációs és kohéziós növekedési pólusokban összpontosulnak.

25 Prioritása a produktiv mezőgazdaság, erdőgazdaság és feldolgozóipar támogatása rákapcsolódva a modernizációra, innovációra, szerkezeti átalakításra és a tudás átadására az agráriumban, az élelmiszeriparban és az erdógazdaságban.

${ }^{26}$ Prioritása a vidéki életkörnyezet javítása és védelme - a biodiverzitás megórzése, a víz- és talajvédelem, az éghajlati változások hatásainak mérséklése.

27 Prioritása a munkahelyteremtés és gazdasági aktivitás támogatása a vidéki térben.

28 Prioritása a vidéki tér fejlődési potenciáljának mobilizálása, a fejlesztés menedzsmentjének és irányításảnak javítása, a helyi kezdeményezések támogatása. (A LEADER, mint Közösségi Kezdeményezés Szlovákiában új formaként jelenik meg a vidéki közösségek fejlesztésében, ugyanis a 2004-2006 időszakban Szlovákiában nem volt a támogatási keretek között számos uniós államtól eltéröen.)

29 European Territorial Cooperation - ETC. 
Lelkes Gábor: A szlovákiai regionális fejlesztéspolitika s annak középtávú dél-szlovákiai határ menti vetülete az uniós támogatáspolitika tükrében. - Tér és Társadalom 22. évf. 2008/3. 151-184. p. A szlovákiai regionális fejlesztéspolitika... 183

\section{Irodalom}

Hardi T-Mezei I. (2003). A szlovák közigazgatás és területfejlesztés asszimetriái. - Tér és Társadalom. 4. 126-154. o.

Koncepcia decentralizácie a modernizácie verejnej správy. (2001) (A közigazgatás decentralizálásának és modernizációjának a terve) Úrad vlády SR, Bratislava.

Koncepcia územného rozvoja Slovenska 2001. (2002) (Szlovákia Teruletfejlesztési Koncepciója 2001) Ministerstvo životného prostredia Slovenskej republiky, Bratislava.

Mezei, I. (2006) Chances of Hungarian-Slovak Cross-Border Relations. Discussion Paper. 49. Centre for Refional Studies of Hungarian Academy of Sciences, Pécs.

Národný rozvojový plán (2003) (Nemzeti Fejlesztési Terv) Ministerstvo výstavby a regionálneho rozvoja Slovenskej republiky, Bratislava.

Národný strategický plán rozvoja vidieka SR na roky 2007-2013. (2006) (Nemzeti Stratégiai Vidékfejlesztési Terv 2007-2013) Ministerstvo pôdohospodárstva Slovenskej republiky, Bratislava.

Národný strategický referenčný rámec Slovenskej republiky 2007-2013. (2006) (Szlovák Köztársaság Nemzeti Stratégiai Referencia Kerete 2007-2013) Ministerstvo výstavby a regionálneho rozvoja Slovenskej republiky, Bratislava.

Program hospodárskeho a sociálneho rozvoja Banskobystrického samosprávneho kraja. (2007) (Besztercebányai önkormányzati kerület gazdasági és szociális fejlesztési programja) Banskobystrický samosprávny kraj, Banská Bystrica.

Program hospodárskeho a sociálneho rozvoja Bratislavského samosprávneho kraja. (2007) (Pozsonyi önkormányzati kerulet gazdasági és szociális fejlesztési programja) Bratislavský samosprávny kraj, Bratislava.

Program hospodárskeho a sociálneho rozvoja Košického samosprávneho kraja. (2007) (Kassai önkormányzati kerület gazdasági és szociális fejlesztési programja) Košický samosprávny kraj, Košice.

Program hospodárskeho a sociálneho rozvoja Nitrianského samosprávneho kraja. (2007) (Nyitrai önkormảnyzati kerület gazdasági és szociális fejlesztési programja) Nitriansky samosprávny kraj, Nitra.

Program hospodárskeho a sociálneho rozvoja Trnavského samosprávneho kraja. (2007) (Nagyszombati önkormányzati kerulet gazdasági és szociális fejlesztési programja), Trnavský samosprávny kraj, Trnava.

Régiók statisztikai évkönyve. (2007) Szlovák Köztársaság Statisztikai Hivatala, Bratislava.

Slovensko 2006 (2007) Inštitút pre verejné otázky, Bratislava.

Tóth K. (2005) A magyar intézményrendszer fejlódése. - Fazekas, J.-Hunčík, P. (szerk.) Magyarok Szlovákiában (1989-2004). Fórum Kisebbségkutató Intézet - Lilium Aurum Könyvkiadó, SomorjaDunaszerdahely.

\section{REGIONAL DEVELOPMENT POLICY IN SLOVAKIA AND ITS MEDIUM TERM APPEARANCE IN SOUTHERN SLOVAKIA'S BORDER REGIONS REGARDING THE DEVELOPMENT ASSISTANCE POLICY OF THE EUROPEAN UNION}

\section{GÁBOR LELKES}

The study deals with the development of regional development policy-making in Slovakia within the last 10 years and in relation to the country's EU membership. The essay further explores the Slovak-Hungarian cross-border corporation attitude in the regional development strategies of the Southern Slovakia's regional self-governments.

The first steps towards the decentralized coordination of the regional development were made in 1999 [in the period 1989-1998 regional development was still characterized by topdown approach]. Since 1999 the country has realised comprehensive reforms in public administration with fiscal decentralization, recently local and regional self-governments have real power to influence the development of their environments. Actors of regional develop- 
Lelkes Gábor: A szlovákiai regionális fejlesztéspolitika s annak középtávú dél-szlovákiai határ menti vetülete az uniós támogatáspolitika tükrében. - Tér és Társadalom 22. évf. 2008/3. 151-184. p.

ment have recognized that the space does not end at the border - after 2000 in many border regions there was a boom of cross-border cooperations [intersettlement, interregional and interinstitutional cooperations].

Slovakia's entry to the European Union made huge effect on the financial resources available for regional development. During the programming period 2007-2013 Slovakia has the chance to get approximately 14 billion EUR from the EU on the issues of regional development. However to achieve cohesion of Slovakia's regions is necessary to give up the use of the Slovak nationalistic approach in regional development policy-making, to which the southern regions inhabited by Hungarians often fall victim (regions and municipalities inhabited by Slovaks, which are already more developed, are the major beneficiaries). 